Revista Brasileira de Cartografia

ISSN 1808-0936 | https://doi.org/10.14393/revbrascartogr

Sociedade Brasileira de Cartografia, Geodésia, Fotogrametria e Sensoriamento Remoto

\title{
Cartografia e Direito na Formação Territorial e na Configuração da Propriedade no Brasil
}

\section{Cartography and Law in Territorial Formation and Property Configuration in Brazil}

Claudia Robbi Sluter ${ }^{1}$, Andrea Flávia Tenório Carneiro ${ }^{2}$, Andrea Lopes Iescheck ${ }^{3}$, Daniela Regina Pontes ${ }^{4}$ e José Antônio Peres Gediel ${ }^{5}$

1 Universidade Federal do Rio Grande do Sul, Departamento de Geodésia, Porto Alegre - RS, Brasil. robbi.sluter@ufrgs.br ORCID: https://orcid.org/0000-0002-6765-9526

2 Universidade Federal de Pernambuco, Departamento de Engenharia Cartográfica, Recife -PE, Brasil. andreaftenorio@gmail.com. ORCID: http://orcid.org/0000-0002-2445-2330

3 Universidade Federal do Rio Grande do Sul, Departamento de Geodésia, Porto Alegre - RS, Brasil. andrea.iescheck@ufrgs.br ORCID: http://orcid.org/0000-0002-8390-435X

4 Universidade Federal do Paraná, Departamento de Geomática, Curitiba, Brasil. danielepontes.ufpr@gmail.com

ORCID: https://orcid.org/0000-0003-1043-9327

5 Universidade Federal do Paraná, Departamento de Direito Civil e Processual Civil, Curitiba, Brasil. jagediel@gmail.com ORCID: https://orcid.org/0000-0002-4139-8559

Resumo: O diálogo entre Cartografia e Direito permite discutir e avaliar as consequências históricas dos processos de demarcação de terras e de titulação, e do registro de propriedades, no Brasil. Esse diálogo entre áreas do conhecimento orienta o desenvolvimento de pesquisa, com viés interdisciplinar, que busca recuperar, em suas respectivas áreas, o percurso histórico de técnicas e normas. Por isso, o debate produzido e as questões formuladas nesta pesquisa dizem respeito à necessidade de integração entre o mapeamento topográfico sistemático e o cadastro territorial; à ausência do mapeamento topográfico; aos problemas jurídicos de demarcação e titulação de terras públicas e privadas; e ao diagnóstico da situação atual do cadastro territorial e sua relação com o mapeamento topográfico sistemático. Este artigo apresenta, assim, os argumentos com os quais se estabelece um projeto de pesquisa cujo principal objetivo é entender as consequências históricas da ausência de mapeamento topográfico na demarcação e no registro de propriedades no Brasil, e sua relação com o arcabouço normativo vigente. As análises compartilhadas entre os pesquisadores deste grupo de pesquisa denotam as ausências e as contradições que apontam para a necessidade de busca de elementos conceituais, problematizações e questionamentos comuns na identificação e solução dos problemas.

Palavras-chave: Mapeamento topográfico sistemático. Cadastro territorial. Legislação territorial.

\begin{abstract}
The dialogue between cartography and law allows us to discuss and evaluate the historical consequences of land demarcation, titling, and registration in Brazil. This dialogue between areas of knowledge guides the development of interdisciplinary research, seeking to recover, in their respective areas, the historical path of techniques and regulation. Therefore, the discussion and the questions formulated in this research are related to the need for integration between systematic topographic mapping and cadastre; to the lack of topographic mapping; to legal problems of demarcation and titling of public and private lands; and the diagnosis of the current situation concerning cadastre and its relationship with the systematic topographic mapping. Thereby, this paper presents the arguments with which we establish a research project whose primary goal is to understand the historical consequences of the lack of topographic mapping in land demarcation and registration in Brazil and its relationship with the current regulatory framework. The analysis shared among researchers of this group denotes absences and contradictions, which point to the need to search for common conceptual elements, problematizations, and questions in identifying and solving problems.
\end{abstract}

Keywords: Topographic mapping. Cadastre. Territorial legislation. 


\section{CONSIDERAÇÕES INICIAIS}

O presente artigo apresenta os argumentos com os quais foi estabelecido um projeto de pesquisa, que tem como principal objetivo identificar ações que permitam superar as deficiências da ausência de mapeamento topográfico na demarcação e no registro de terras no Brasil, em sua relação com o direito vigente, ao analisar o processo de ocupação territorial e da legislação fundiária e agrária brasileira. A partir dessa lógica, percebese o desalinho cronológico entre a ocupação do território, a legislação e o mapeamento do território.

O mapeamento topográfico é a referência espacial para qualquer atividade da sociedade voltada ao planejamento, ao uso e à ocupação do território. Já o cadastro territorial, implementado para descrever o relacionamento entre pessoa e terra, deve servir de base para as ações voltadas para o gerenciamento da terra e do uso do solo, inclusive o planejamento territorial, e apoiar o desenvolvimento sustentável e a proteção ambiental. Este é o conceito proposto em FIG (1995), que tem sido adotado por várias outras instituições e autores, como UNECE (2005), Williamson et.al. (2010), dentre outros. Portanto, um cadastro eficiente e eficaz depende de um mapeamento que represente os limites das unidades espaciais de acordo com a sua situação jurídica, estabelecendo uma relação de interdependência entre tais sistemas. É nesse contexto que Cartografia e Direito são aqui convidados a um encontro que produza uma perspectiva de análise interdisciplinar sobre as conformações, representações e interpretações do retrato da territorialidade brasileira contemporânea, a partir da recuperação de eventos e circunstâncias que marcaram sua passagem e permanência no tempo.

Se na forma as duas grandes áreas apresentam linguagens particulares e distintas, no conteúdo e finalidades percorrem juntas trechos consideráveis dos caminhos que construíram. Assim, produzem oficialidades e legitimidades na descrição, na apropriação, no uso, na ocupação, na justificação, no controle e poder sobre a terra, consideradas as mais variadas hierarquizações que repercutem no desenho das fronteiras, inclusive dos pertencimentos e identidades e, portanto, nos modos de realização da vida e das relações com o espaço.

Nas diferentes epistemologias, cada área do conhecimento, ao traçar as suas linhas argumentativas, estabelece na diversidade de seus campos de análises a produção de realidades e, portanto, os quadros que habitam o imaginário da invenção social da terra (MAIA, 2008), especialmente da terra "Brasilis", identificado a partir da formação violenta da constituição de um território de colonização. O corte temporal que não ignora ou minimiza toda a realidade pré-existente se impõe na hegemonia das formas assumidas com o evento da invasão e das bruscas rupturas que vão se somando no tempo. O percurso histórico do entrelaçamento da Cartografia e do Direito tem lugar nesse ambiente absolutamente imposto e influenciado pelo modo como o agente externo pratica o que entende por ordenação e controle e que toma forma na figura do Estado-nação. Nesse ambiente, normas de definição de política de organização do território e do início da constituição das unidades territoriais e seus respectivos domínios políticos, administrativos e formais ganham notoriedade e, com essa perspectiva sobre as duas disciplinas pesa a expectativa de aportes de segurança e de respostas que afirmem ou confirmem determinadas "realidades", com base na técnica que pretende certeza e precisão, com os seus instrumentos por excelência, o mapa e a lei que constroem os fundamentos da institucionalidade que confere formalidade à gestão da terra.

Parte-se aqui da constatação que Cartografia e Direito, tal como se apresentam, são produtos de um mesmo tempo histórico e servem às finalidades da conquista colonial e dos Estados nacionais. O início do século XIX, dada a conformação dos Estados e a preocupação com os controles e o planejamento territorial, alterou a concepção dos mapeamentos e dos direitos territoriais. A França, com o cadastro napoleônico, muda a dimensão, a escala e a proposição de conteúdo dos mapas ao mesmo tempo em que o Código Civil napoleônico também estabelece as novas figuras apropriativas da terra, com o surgimento da divisão públicoprivado e do regime de propriedades e posses. Influenciados pelos modelos europeus, porém, em contexto e condições absolutamente diversas, tenta-se estabelecer no Brasil, especialmente no pós-independência, o início de políticas de Estado que previam a implementação das bases cartográficas e a inauguração de regulações sobre a destinação de terras públicas para a constituição de propriedades privadas, que pode ser observado inicialmente com o advento da Lei de Terras em 1850. Dadas as condições precárias e o ambiente completamente hostil a tais novidades, o que se apresenta é a não coincidência entre o discurso, a prática e a 
realidade. Do ponto de vista da Cartografia, soma-se às distorções da "Carta do Império do Brasil" de caráter ilustrativo, a nova previsão de regime apropriativo definido na primeira Constituição (1824), a propriedade privada. Esse regime de apropriação previa a definição exata das unidades territoriais, o que se constituía em um "inverídico institucional".

O Brasil nunca dispôs de um mapeamento de referência completo, atualizado e nas escalas necessárias para a implementação de um cadastro territorial que pudesse apoiar políticas fundiárias e atender devidamente o ordenamento jurídico que se refere às questões territoriais. Atualmente, o mapeamento disponível corresponde a 5\% do território brasileiro na escala 1:25.000 e 24\% na escala 1:50.000 (SLUTER et al., 2018), o que é insuficiente tanto para apoiar o cadastro territorial como para aplicar a legislação referente ao ordenamento territorial.

Alguns conceitos básicos de Cartografia são aqui explicitados, devido à importância de se entender precisamente seus significados. As cartas topográficas são um tipo de mapas de referência geral (SLOCUM et al., 2008), e portanto, o mapeamento topográfico é um mapeamento de referência. Contudo, o inverso não é necessariamente verdadeiro. Este entendimento é importante, pois um dos marcos históricos, e que é fundamental para a análise aqui apresentada, é o mapeamento da França, conhecido como o "mapa da França de Cassini" (THROWER, 2008). Este mapeamento estabeleceu o mapeamento sistemático terrestre, denominado de mapeamento topográfico. Desde o mapeamento da França de Cassini, o mapeamento topográfico é o mapeamento que apresenta em seus produtos a mais alta acurácia e precisão, possibilitadas pela tecnologia vigente. Assim, é este mapeamento que deve ser a referência espacial para qualquer atividade da sociedade voltada ao planejamento, ao uso e à ocupação do território. Também importante é entender que qualquer representação gráfica do meio ambiente pode ser denominada de mapa e, portanto, qualquer produto da Cartografia pode ser chamado de mapa. Quando é necessário se estabelecer algumas distinções entre a evolução histórica das medições e representações gráficas de usos agrícolas e ocupações urbanas, deve-se se considerar também as representações cartográficas denominadas de plantas. Neste artigo usa-se estas duas denominações: planta e mapa. As plantas são representações cartográficas de pequenas regiões da superfície terrestre, que utilizam como superfície de referência o plano topográfico.

Esta pesquisa e os resultados parciais apresentados neste artigo permitem entender as consequências históricas da demarcação e registro de propriedades no Brasil a partir do estabelecimento de categorias comuns de análise. Para entender as relações e as dependências do direito com o mapeamento topográfico e com o cadastro territorial, as discussões aqui conduzidas dizem respeito ao cadastro moderno e suas relações com a história da cartografia topográfica; à formação do território e da propriedade no Brasil; à ausência do mapeamento topográfico e o problema da demarcação de terras no Brasil; e ao diagnóstico da situação atual do cadastro territorial e sua relação com o mapeamento topográfico sistemático.

\section{O CADASTRO MODERNO E SUA RELAÇÃO COM A HISTÓRIA DA CARTOGRAFIA TOPOGRÁFICA}

As mais antigas representações cartográficas conhecidas mostram delimitações de áreas de culturas agrícolas, como no Vale Camonica, Itália (ARCÀ, 2004), e das moradias de Çatalhöyük na região de Anatolia, Turquia (CLARKE, 2013), as quais são do período neolítico. Os mapas mais antigos da História foram encontrados na região da Mesopotâmia e foram construídos pelos babilônios. Entre estas descobertas, encontra-se uma planta de parte da cidade de Nipur, onde estão desenhados canais de diferentes larguras, um muro da cidade com seus portões e um fosso, casas e seus quintais, entre outras feições. Esta planta foi construída em uma placa de barro em 1500 AC. O mapa mais antigo, conhecido como o mapa de Acádia, também foi construído pelos babilônios, data de 2300 AC, e representa a Mesopotâmia. Este mapa é orientado para leste, que está na sua parte superior (topo), e algumas feições são claramente identificadas, tais como: cursos d'água, assentamentos e montanhas. Os babilônios também construíram o mapa do mundo mais antigo, datado de 600 AC. Este mapa mostra como os assírios entendiam o mundo, ou seja, a Mesopotâmia no centro (visão egocêntrica) com um oceano que circunda as terras, o Oceano Terrestre, e os lugares distantes, as Sete Ilhas, ilustradas por triângulos. Também, está representado o Rio Eufrates, desde a sua nascente nas montanhas da Armênia até a sua foz no Golfo Pérsico. Várias cidades são desenhadas com círculos, sendo algumas 
identificadas por seus nomes (THROWER, 2008; MILLARD, 1987).

Os estudos sobre os mapas encontrados na Mesopotâmia mostram que o mapa de Acádia, ou seja, a planta de uma parte da cidade de Nipur, está representado em uma escala grande, com precisão nas formas geométricas e nas medidas de distâncias. Por outro lado, os mapas da Mesopotâmia e o mapa do mundo dos Assírios são representações gráficas do entendimento dos assírios e babilônios sobre estas regiões. Na mesma placa de barro em que está desenhado o mapa do mundo, encontra-se um texto que o descreve em escrita cuneiforme. Com este texto é possível entender os significados astrológico e religioso deste mapa. Tanto a representação da Mesopotâmia (escala média) como do mundo (escala pequena) são ilustrações do mapa mental dos assírios e babilônios sobre seu entendimento da região que habitavam, a Mesopotâmia, e do mundo (THROWER, 2008; MILLARD, 1987).

Os registros históricos de que os egípcios pagavam impostos e taxas sobre as colheitas de suas terras cultivadas, no Antigo Egito, permite afirmar que eles realizavam as medições de terras e deviam conhecer geometria. Contudo, não há conhecimento sobre desenhos ou mapas que acompanhassem os registros dos levantamentos cadastrais públicos. O registro censitário preservado do Antigo Egito, chamado de Papiro Wilbour, carece dos desenhos das terras (SHORE, 1987).

A forte e importante influência, na História da Cartografia, do período clássico da Grécia está mais relacionado a conhecimentos teóricos do que a soluções práticas que possibilitassem medições terrestres (HARLEY; WOODWARD, 1987). Diferentemente da cultura grega clássica, no Império Romano houve o desenvolvimento de técnicas de medições terrestres, tanto para a construção de mapas cadastrais como para as plantas de engenharia, voltadas para a construção de túneis, aquedutos e sistemas de drenagem. O mapa romano mais antigo de um levantamento de terras é datado entre os anos 170 e 165 AC. Os mapas cadastrais romanos registravam os centuriation ${ }^{l}$, sendo estes parte de um sistema de registro de terras. Além do registro de terras, os mapas cadastrais eram também usados para definir estratégias de governo. Na obra Corpus Agrimensorum ${ }^{2}$ está registrado que o imperador Júlio Cesar foi o fundador de um sistema totalmente organizado de levantamento e de registro de terras. Este sistema foi aprimorado no governo do imperador Augusto (DILKE, 1987).

A palavra "agrimensura" vem do Império Romano e significava medir terras. É na Agrimensura que o termo levantamentos terrestre ${ }^{3}$ tem origem. Mediante um processo técnico/jurídico/administrativo rigorosamente estabelecido, técnicos realizavam o levantamento cadastral de lotes de terrenos conquistados e o trâmite era documentado em placas de bronze, madeira ou mármore denominadas formas ou aes, nas quais eram incluídas as informações cadastrais: extensão de cada lote; nome dos proprietários e lotes atribuídos; e categoria, origem e regime jurídico. Esses registros eram elaborados em duas cópias, uma das quais era enviada ao arquivo municipal ou colonial e a outra era arquivada no tabularium de Roma. Tais levantamentos incluíam uma parte escrita e outra gráfica (ÁLCAZAR MOLINA, 2007; DILKE,1987).

Esta distinção entre uma representação em planta em escala grande, resultado de medições realizadas em campo, e das representações de grandes extensões da superfície terrestre, tal como a Mesopotâmia e o mundo, em escalas menores, que mostram as relações espaciais observadas e imaginadas, contudo não medidas, é importante para entender que a evolução do mapeamento de pequenas regiões, como terras agriculturáveis, vilas e cidades, e o mapeamento de reinados ou do mundo, a Cartografia realizada com a cosmografia, ocorreram separadamente por séculos. Estas duas atividades profissionais e, consequentemente, seus trabalhos técnicos eram desenvolvidos independentemente. Isto significa que por séculos as técnicas desenvolvidas para levantamentos terrestres não foram usadas para a construção de mapas, como também as técnicas para determinar latitude e longitude não foram usadas na medição de terras. A combinação de métodos e técnicas desenvolvidos na Cartografia e nos Levantamentos Terrestres possibilitou o mapeamento de uma grande extensão da superfície terrestre, tal como o reinado da França, com detalhamento e precisão. Por outro

\footnotetext{
${ }^{1}$ (Oxford Dictionary) História Romana: o método, processo ou prática de dividir terras agrícolas em padrões regulares de "centurias", especialmente como parte da fundação de uma colônia.

2 (Wikipedia) O Corpus Agrimensorum Romanorum é um livro romano sobre levantamentos de terras que reúne os trabalhos de Siculus Flaccus, Frontinus, Agennius Urbicus, Hyginus Gromaticus e outros escritores.

${ }^{3}$ (Dicionário Houaiss) Medição de terras e campos; arte ou técnica dessa medição.
} 
lado, o desenvolvimento do mapeamento topográfico por Colbert e Cassini proporcionou o estabelecimento dos métodos e técnicas para o cadastro de Napoleão, que é o marco fundamental do cadastro moderno.

Com os desenvolvimentos dos conhecimentos científicos no século XVII surgem duas instituições que tiveram papéis fundamentais no desenvolvimento de métodos e técnicas que possibilitaram o mapeamento da França de Cassini. Estas instituições são a Académie Royale des Sciences da França e a Royal Society, formalmente The Royal Society of London for Improving Natural Knowledge do Reino Unido. Os membros destas academias de ciências se dedicaram a entender e a solucionar um conjunto grande de problemas científicos, incluindo questões relacionadas com precisões de mapeamentos e cartas para navegação. Um dos ilustres cientistas britânicos é Edmond Haley, que é o autor do mais antigo mapa temático conhecido, o mapa de isogônicas do Canal da Mancha (THROWER, 2008).

Mesmo com os grandes avanços nos métodos científicos para as determinações astronômicas e o surgimento e desenvolvimento de triangulações geodésicas, que proporcionaram a produção de mapas de grandes extensões, ainda no final do século XVII não havia mapas em escalas grandes o suficiente, de todo um reinado, que pudessem ser usados para rotas de transportes, planejamento da administração pública e estratégias táticas e militares. O primeiro mapeamento com acurácia e precisão suficiente que permitisse sua publicação em uma escala muitas vezes maior do que até então praticada, de todo um país, e, portanto, em folhas de papel com seus limites formando um quadriculado limitado por paralelos e meridianos, foi o mapeamento da França, conhecido como Mapa da França de Cassini (KONVITZ, 1983; THROWER, 2008).

A proposição do mapeamento da França foi de Jean-Batiste Colbert e do ministro das finanças de Luis XIV, que tiveram o apoio da corte francesa da época, em 1668. Para realizar o mapeamento, Colbert propôs a contratação do astrônomo italiano chamado Giovanni Cassini, na época professor na Universidade de Bolonha, Itália. Em 1669, Giovanni Cassini foi convidado pelo Rei Luís XIV para ser cientista na Académie Royale des Sciences da França, e em 1670 foi nomeado diretor do Observatório de Paris. A primeira tarefa para a realização deste mapeamento foi a medição do comprimento de um arco do Meridiano de Paris. Esta tarefa foi realizada por Abbé Picard, um notável geodesista, pelo método de triangulação geodésica. Com base na triangulação de Picard foram construídas 9 cartas topográficas da região de Paris. Picard veio a falecer em 1682, e os trabalhos de triangulação foram continuados, os quais se estenderam desde a costa do Canal da Mancha até os Pirineus. A materialização de marcos geodésicos por toda a França, realizada por triangulação geodésica, possibilitou a produção de cartas topográficas de todo um país, com uma acurácia e precisão maior do que qualquer mapeamento já realizado. Consequentemente, foi também possível produzir as cartas topográficas em uma escala bem maior do que até então se havia mapeado grandes extensões de terra, neste caso 1:86.400 (THROWER, 2008).

Por suas características, o mapeamento da França de Cassini estabeleceu o método para a realização de mapeamento topográfico sistemático, que depois foi seguido em diversos lugares, e até hoje é padrão para realização deste tipo de mapeamento (THROWER, 2008). O grande desafio de se mapear todo um reinado, extenso como o Reinado da França, somente foi possível porque brilhantes geodesistas e cartógrafos, trabalhando cooperativamente, estabeleceram o método que, ainda atualmente, é o método moderno para a realização do mapeamento topográfico sistemático. Este método é composto de quatro grandes etapas: (1) Estabelecimento e materialização de um sistema geodésico de referência; (2) Estabelecimento dos métodos e técnicas de levantamento das feições; (3) Definição da divisão do território em articulação de mapas; e (4) Desenho acurado das feições e preparação da representação cartográfica para a reprodução. Além da articulação de folhas, este mapeamento foi concebido para ser executado com padrões para os símbolos, os quais representam o mesmo conjunto de feições em todos os mapas.

Graças às suas competências em Geodésia e Cartografia, a França do século XIX, melhor que qualquer outro país da Europa, estava tecnicamente bem preparada para desenvolver um cadastro moderno, com destinação mais abrangente do que as finalidades fiscais para as quais era implementado até então (PHILIPS, 2003). Entre 1793 e 1794, a Assembleia Constituinte da Revolução Francesa decretou a organização do Cadastro Geral da Nação e a avaliação de todos os bens de raiz. Em 23 de novembro de 1798 foi publicada uma lei que regulamentou o imposto predial. Em 1801, o então primeiro cônsul Napoleão estabeleceu uma comissão para estudar a distribuição equitativa do imposto predial. Em 1807, foi publicada a lei intitulada 
Instruções Relativas ao Cadastro, contendo as bases para a sua execução. Em 1807, foi criada uma comissão para desenvolver um projeto de levantamento sistemático, classificação e avaliação de mais de 100 milhões de parcelas. O projeto foi aprovado, iniciado em 1808 e concluído em 1850. Em 1811, publicou-se um compêndio, o Recueil Méthodique des Lois, Décrets, Regléments, Instructions et Décisions sur le Cadastre de France, com todas as leis, decretos, regulamentos e instruções relativos a cadastro. Segundo Williamson (1983), uma das contribuições mais importantes do cadastro francês foi o reconhecimento da importância de mapas em grande escala e de um levantamento cadastral sistemático para o estabelecimento de um cadastro moderno. Apesar desse cadastro ter sido estabelecido com fins fiscais, Napoleão entendia que o trabalho de levantamento poderia ser utilizado para outras finalidades, inclusive como garantia de propriedade.

Jean-Courret (2020) detalha todo o processo de concepção e execução do cadastro napoleônico, nos seus aspectos legais, administrativos e técnicos, destacando a importância histórica do conjunto de documentos produzidos na época. Sobre as questões técnicas envolvidas, o autor descreve o levantamento ao nível das parcelas, cuja identificação constava no mapa e integrava cada unidade aos dados descritivos sobre as pessoas que tinham relação com cada parcela. O mapa fornecia uma representação completa, cuidadosa e precisa da ocupação da terra e da distribuição dos espaços construídos e não construídos, informação essencial para o cálculo dos tributos.

Bullock (1983) sumariza as principais etapas da compilação do cadastro francês, apresentadas por Dowson e Sheppard em 1956 (apud BULLOCK, 1983): (a) estabelecimento de uma rede local de triangulação; (b) elaboração da lista de proprietários, com respectiva taxa de imposto e delineação das parcelas; (c) definição da parcela como uma porção da superfície da terra dividida por qualquer limite físico, sujeita ao mesmo uso e encargos e possuída pela mesma pessoa; (d) os proprietários foram notificados e encarregados da realização do levantamento de suas propriedades; (e) numeração das parcelas de forma única sobre planos compilados nas escalas de 1:1.250 a 1:2.500. Também foram compilados mapas índices nas escalas de 1:5.000 a 1:10.000; (f) cálculo das áreas das parcelas; (g) compilação de um índice das parcelas mostrando os nomes e endereços dos proprietários, as parcelas possuídas por cada um, a natureza do cultivo e outros detalhes, como construções; (h) publicação dos resultados dos levantamentos. As reclamações foram investigadas e as correções efetuadas, quando necessárias; (i) cada parcela foi, então, classificada de acordo com o seu uso, o preço avaliado e a taxa de imposto calculada individualmente; (j) compilação de um índice de proprietários por ordem alfabética; (k) inicialmente, os índices das parcelas e dos proprietários eram atualizados anualmente a partir de listas fornecidas pelo Registro de Imóveis.

O cadastro francês, considerado o marco inicial do cadastro moderno, surge alguns anos após o mapeamento topográfico de Cassini. A construção de um mapeamento topográfico em escala grande e alta acurácia só foi possível porque Colbert e Picard realizaram uma mediação de um arco de meridiano (o meridiano de Paris) com acurácia e precisão suficientes para ser a base do mapeamento em uma escala maior que 1:100.000. E, para que o mapeamento de toda a França fosse realizado na mesma escala e com precisão e acurácia homogêneas, houve a necessidade de se estabelecer uma rede de marcos geodésicos em todo o território. Quando a Assembleia Constituinte da Revolução Francesa decreta a organização do Cadastro Geral da Nação, e alguns anos depois são publicadas todas as leis, decretos, regulamentos e instruções relativos a cadastro, um sistema geodésico detalhado já havia sido implementado em todo o território francês. Desde o mapeamento da França de Cassini e o Cadastro Geral da Nação francesa, sabe-se que para que o mapa cadastral represente com precisão a ocupação da terra, há a necessidade de se ter o mapeamento topográfico terrestre, com um sistema geodésico de alta precisão e constantemente em manutenção. 


\section{IMPRECISÃO E ADAPTAÇÃO DOS INSTRUMENTOS JURÍDICOS COMO ESTRATÉGIAS DE PODER NA FORMAÇÃO TERRITORIAL BRASILEIRA}

\subsection{Constituições do modelo normativo jurídico-cartográfico}

A empreitada colonial precisou dominar territórios (espaços moldados por povos originários), para extrair produtos com valor comercial na Europa. Para estabelecerem esse domínio, as Metrópoles coloniais lançaram mão de três instrumentos concomitantes e interdependentes: o direito; a cartografia; e a guerra. Esses instrumentos são pensados a partir da organização social feudal, antes da expansão da economia mercantil marítima que extrapolou os limites do Mediterrâneo, no final do século XV. Esses instrumentos foram adaptados às finalidades da nova formação social econômica e política que começou a se afirmar na Europa, nesse período. A utilização desses instrumentos diante de novos desafios foi sempre precária, mas gerou efeitos.

O denominado Tratado de Tordesilhas (1494), por exemplo, é um típico instrumento jurídico do "direito da guerra", pois teve como finalidade prevenir conflitos (guerras) entre as potências coloniais de Portugal e Castela, a respeito do domínio político do território e da titularidade jurídica das terras no recémdescoberto Continente Americano, antes mesmo dos portugueses terem aportado na atual costa brasileira, em 1500. Esse tratado decorre da mediação da autoridade papal, aspecto central da política dos reinos durante o feudalismo e tinha como objeto definir fronteiras de terras desconhecidas, muitas a serem conquistadas e outras inexistentes, nos termos imaginados e descritos por viajantes e cronistas medievais. Tanto é assim que o domínio português foi fixado por esse tratado "cerca de trezentas e sessenta léguas a oeste da Ilha dos Açores" revelando o desconhecimento e a imprecisão de informações sobre o mundo a ser conquistado. Trata-se, sem dúvida, de uma abstração jurídica, que só iria se concretizar pela guerra aos povos originários e pelos posteriores conflitos do Brasil com países fronteiriços colonizados pela Espanha. Imprecisão e abstração jurídica que passam de uma inadequação a uma estratégia de expansão territorial que o Brasil vai se utilizar, até a Primeira República, na denominada Guerra do Acre, contra a Bolívia.

O domínio político de toda a extensão territorial indicada pelo Tratado de Tordesilhas também é justificado por uma fórmula retirada da experiência jurídica romana e assimilada pelo direito internacional da guerra, sintetizada na expressão latina "uti possidetis, ita possideatis" (como possuis, assim possuis), ou seja, como já possuís de fato, continuas a possuir de direito. Essa fórmula permitia ao vencedor na guerra se tornar senhor legítimo dos bens do vencido e estabelecer o domínio pleno sobre a terra. No caso brasileiro, a novidade é que a guerra sequer havia começado, mas já se prenunciava a vitória. A partir dessas estratégias jurídicas, o reino de Portugal iniciou o processo de ocupação militar e exploração econômico-comercial do Brasil, a partir da costa, e começou a determinar a titularidade jurídica das terras da Colônia. Assim, o processo de formação territorial e da apropriação de terras no Brasil se inicia em 1530, sob o controle absoluto do reino de Portugal e de seu soberano.

Cabe assinalar que, no período colonial, o domínio jurídico sobre a totalidade das terras da Colônia foi atribuído à Coroa portuguesa e à Ordem de Cristo, organização vinculada à Igreja de Roma, cujo grão-mestre era, coincidentemente, o rei de Portugal. Note-se, ainda, que o reino de Portugal considerou vagas todas as terras deste território, ao desconsiderar a presença de povos originários que aqui habitavam. Para realizar a operação de conquista, o Estado colonial português lançou mão, várias vezes, de estratégias militares e utilizou diferentes instrumentos jurídicos já existentes no Reino ao conceder terras a seus súditos capazes de explorar economicamente a Colônia, fossem eles residentes ou não no Brasil.

O instrumento mais importante para a concessão de terras foi o das Sesmarias, inspirado, como descreve Paulo Carneiro Maia, na legislação da dinastia Borgonha de Dom Fernando I, no ano de 1375, reformulada nos termos definidos pelas Ordenações do Reino (MAIA, 1955), em que o seu conceito estava atrelado a uma parcela ou porção de terra havida por um súdito de uma concessão de titularidade registrada e resguardada por ato do soberano dependente do ato simbólico da tomada de posse da terra pelo beneficiário. No regime jurídico das Sesmarias, caso o súdito beneficiado com a concessão não a ocupasse, tornando-a, efetivamente, produtiva pelo cultivo, em um prazo de até cinco anos, deveria devolvê-la à Coroa. Essa condição resolutiva do direito português não foi aplicada no Brasil e os beneficiários das Sesmarias não sofreram 
qualquer sanção por não terem cultivado a terra, até porque o empreendimento colonial, inicialmente, visava apenas à extração de recursos naturais que independiam do cultivo. Há quem aponte nesta característica da ocupação territorial e na ausência de fiscalização pela Coroa a origem mais remota dos latifúndios improdutivos no Brasil. Posteriormente, a Coroa passou a exigir a confirmação da concessão régia das Sesmarias e o pagamento de quantia anual, como controle formal do cumprimento das obrigações do sesmeiro.

O "Sistema Sesmarial" no Brasil foi, assim, a fórmula jurídica aplicada para, sob condição de realização de determinados critérios, transferir terras do domínio da Coroa portuguesa (que hoje denominaríamos terras públicas) para particulares, até o ano de 1822, data da independência política da Colônia e da instalação do Império, ainda vinculado à Metrópole por laços familiares da monarquia lusitana. Destaquese que, de acordo com a norma, as Sesmarias que tivessem sido medidas, lavradas, demarcadas ou confirmadas válidas seriam reconhecidas, após 1822, pelo poder imperial. Essas sesmarias, no entanto, conformavam apenas a minoria do sistema. A maioria das terras que não apresentava todos esses registros, muitas vezes por terem como beneficiários destas concessões, pessoas que ocupavam posições de destaque no aparato administrativo do novo Estado monárquico, continuaram dispondo das terras, mesmo diante das imprecisões e problemas que já eram reconhecidos desde o Alvará de 5 de outubro de 1795.

O texto de justificativa do Alvará já apontava os prejuízos sobre a ausência de critérios de medição, delimitação e distribuição de terras. Somando-se a isso, também não havia profissionais hábeis à realização do ofício para a totalidade das terras brasileiras (PINTO, 2001) e, nesse sentido, as sesmarias passaram a representar o primeiro grande problema formal fundiário brasileiro trazido da colonização além de, evidentemente, carregar as fraudes e a desigualdade territorial dentre outras questões de conteúdo já indicadas.

Os instrumentos jurídicos do reino foram, pouco a pouco, sendo adaptados às necessidades do empreendimento colonial e os títulos de terras concedidos com base nessas adaptações foram validados pelas legislações posteriores do Império, constituindo a base dos títulos de propriedade no Brasil. Com a independência do Brasil, a Constituição do Império de 1824 acolheu, em parte, as ideias liberais sobre propriedade privada, mas garantiu a continuidade dos concessionários de sesmarias, e, embora tenha ocorrido a ruptura com o sistema político colonial, as fórmulas jurídicas do direito do Reino continuaram vigentes.

Entre 1822 e 1850, as constantes alterações políticas do Império, a insatisfação das elites políticoeconômicas nas províncias e, ainda, a indefinição do regime jurídico sobre terras fizeram com que os instrumentos do direito caíssem em desuso ou fossem distorcidos e adaptados a todas essas situações. Nesse mesmo período e por conta desses mesmos fatores, novas e significativas parcelas de terras foram objeto de ocupação por posse, quase sempre exercida pelos detentores da sesmaria ou por súditos influentes da elite local. Essas posses também foram a base para a consolidação do regime jurídico da propriedade privada estabelecido na segunda metade do século, para alinhar o domínio sobre terras às exigências do capitalismo brasileiro sustentado pela exportação de produtos agrícolas. Conforme já anotado, após 1822, em virtude da independência política do Brasil, o regime jurídico original das Sesmarias foi abolido, mas o Império brasileiro continuou a conceder títulos a particulares, utilizando cartas régias, que em tudo se assemelhavam às Sesmarias e tinham seu registro efetuado junto às paróquias da Igreja Católica.

Até 1850, não havia uma legislação detalhada regulando a concessão de títulos imobiliários, embora a Constituição de 1824 reconhecesse o direito à propriedade privada e o direito excepcional à desapropriação. Ao lado das áreas tituladas por meio de Sesmarias ou de cartas régias, expandiam-se as posses, em áreas ocupadas, cujos possuidores, plenos, diretos ou indiretos buscavam a titulação junto à administração imperial, uma vez que todas as terras não tituladas continuavam sob o domínio jurídico da Coroa imperial brasileira, herdeira da Coroa portuguesa. Muitas dessas posses decorriam da ação de sesmeiros que expulsavam, por conta própria, outros posseiros que não dispunham dos mesmos recursos financeiro e bélico, o mesmo ocorria com a violência da retirada de terras das populações indígenas.

Para constituir um regime de apropriação de terras nos moldes propostos com o instituto da propriedade, pretendia-se, com a Lei n. 601 de 1850, a discriminação das terras devolutas para o devido registro pelo Estado, o reconhecimento oficial da propriedade de terras que apresentassem títulos, a legitimação de posses e para permitir a alienação de terras públicas, especialmente para projetos de colonização de empresas nacionais e estrangeiras. Para tanto, havia a necessidade de constituição de um sistema que desse sustentação 
à nova forma apropriativa. $\mathrm{O}$ órgão destinado à realização dos levantamentos territoriais no Brasil foi nominado como Repartição Geral das Terras Públicas. Em 1850, após a entrada em vigor da Lei de Terras, do mesmo ano, o Regulamento instituidor do órgão definia os profissionais encarregados pelo trabalho, especialmente, engenheiros, os procedimentos de delimitação, a destinação de determinadas terras voltadas à "colonização dos indígenas" e a outras colonizações de brasileiros e de estrangeiros, às povoações e aquelas terras voltadas aos usos públicos comuns, tal como a abertura de estradas e de servidões, o controle de uso sobre terras devolutas e sobre aquelas que podiam ser objeto de alienação pública e, aquelas consideradas terras decorrentes de posse de particulares. O órgão tinha como atribuições, ainda, a definição sobre a medição, divisão, descrição e demarcação de terras devolutas, questão que repercutiria, pela definição de parâmetros, em outras terras ocupadas ou que ainda não fossem objeto de posse.

O organograma estabelecido no Regulamento que tratava das especificidades trazidas pela Lei de Terras, indicava que as províncias teriam os seus próprios órgãos vinculados a um ente central, denominados esses como Repartições Especiais de Terras Públicas, subordinados aos presidentes das províncias, porém, dirigidos por um delegado indicado pelo órgão central, um fiscal e outros oficiais para a realização dos registros nomeados por decreto imperial. As Repartições Espaciais fariam a gestão geral das Comarcas e, ainda, estabeleceriam as relações com os distritos, nos quais haveria profissionais, agrimensores, desenhistas e escreventes, todos nomeados por um inspetor geral, aprovado pelos presidentes das províncias. Com isso se esperava também, a definição de determinados padrões.

As medições tiveram como unidade de medida a braça. Organizadas em quadrados para a subdivisão em lotes, a realização da medição considerava a forma da contagem por corda, sob responsabilidade do agrimensor que deveria fazer três cópias do mapeamento e dos memoriais descritivos. Uma questão que chama a atenção para a época de registro das terras é a de que os trabalhadores na medição e na inspeção de terras recebiam por produtos entregues, não tendo ordenados pagos pelo Estado e, ainda que não se possa afirmar com exatidão o que isso significava, não é desprezível lembrar que dada à ausência de fiscalização efetiva e a conivência de representantes públicos, muitos documentos foram elaborados sem a correspondência ou coincidência com a existência ou com as reais características das terras descritas.

O acesso público aos registros realizados, cartográficos e descritivos em documentos oficiais, poderia ocorrer mediante pagamento de emolumentos. Sobre as terras particulares, a medição se daria nos moldes estabelecidos por aquelas consideradas como devolutas, ocorre que qualquer título considerado como "legítimo", ainda que as terras não fossem medidas, confirmadas ou mesmo cultivadas seriam validadas como propriedades privadas. Os títulos eram confirmados sempre que fosse ratificado o pagamento de impostos pela transferência de terras. Nos casos de legitimação de terras particulares ou da conversão das sesmarias, a realização das atividades concernentes à medição e demarcação seria realizada por Juízes Comissários de Medição, conforme definição do Decreto n. 1318 de 1854:

Art. 35 Os Agrimensores serão pessoas habilitadas por qualquer Escola nacional, ou estrangeira, reconhecida pelos respectivos Governos, e em que se ensine topografia. Na falta de título competente serão habilitados por exame feito por dous Officiaes do Corpo de Engenheiros, ou por duas pessoas, que tenhão o curso completo da Escola Militar, sendo os Examinadores nomeados pelos Presidentes das Províncias.

As medições também tinham por objetivo o registro da legitimação das posses e a definição por limites das terras de terceiros, os vizinhos lindeiros. As terras não demarcadas no prazo estabelecido pelos Presidentes das Províncias para a revalidação e legitimação seriam caracterizadas como terras em comisso. As terras devolutas medidas e demarcadas sem as situações de posse ou de registro de documentos poderiam ser vendidas em hasta pública e os lotes remanescentes poderiam ser adquiridos por particulares diretamente, mediante melhor oferta. Sobre terras reservadas, o Art. 73 definia que:

Art. 73 Os Inspetores, e Agrimensores, tendo notícia da existência de taes hordas nas terras devolutas, que tiverem de medir, procurarão instruir-se de seu gênio e índole, do numero provável de almas, que ellas contêm e da facilidade, ou dificuldade, que houver para o seu aldeamento; e de tudo informarão o Director Geral das Terras Públicas, por intermédio dos 
Delegados, indicando o lugar mais azado para o estabelecimento do aldeamento e os meios de o obter, bem como a extensão de terra para isso necessária.

Os primeiros parcelamentos de solo urbano e rural seriam estabelecidos neste Regulamento de 1850 . Os novos Povoamentos deveriam reservar áreas públicas e os lotes urbanos teriam que apresentar, no mínimo, terrenos com 10 braças de frente (ou testada) e 50 de fundo, sendo os rurais com no mínimo 400 braças de frente e "outras tantas de fundo", e as sobras de terrenos não parcelados divididos em enfiteuses. O planejamento das novas povoações deveria ser realizado pelo Diretor Geral de Terras Públicas.

Considerados os limites e a capacidade dos registros públicos, coube aos Vigários de cada Freguesia a substituição do Estado na tarefa de realização das titulações sendo tais informações publicizadas nas missas. Os registros deveriam ser realizados nos respectivos livros e por cobrarem os respectivos emolumentos. Aqueles que tivessem descobertas declarações falsas poderiam ser condenados ao pagamento de multas e, em alguns casos, a prisão de até três meses. As cópias dos registros eram conservadas no Arquivo das Paróquias e os livros originais encaminhados ao Delegado de Terras Públicas da Província para a organização geral no Registro de Terras.

Diante de todas as dificuldades enfrentadas com a ausência de uma estrutura que desse suporte ao novo sistema proprietário, nova legislação veio tratar do tema, porém, a partir de outras bases. Em 1864, a Lei de Hipotecas incluía em seu texto a instituição e os primeiros procedimentos para o registro geral de terras via transcrição. Essa norma demonstrava de modo cabal, a constituição parcelar da terra, na forma de propriedade, como objeto hábil e de valor econômico passível de ser oferecida em garantia, na modalidade de título que então desvincularia dali para o futuro, a posse do bem, do respectivo titular do direito proprietário, reconhecido pelo Estado. É, portanto, nesse momento em que a terra se torna valor de troca passível de garantia ao credor que se pode considerar o divórcio definitivo entre qualquer necessidade de coincidência entre possuidor e titular do papel que conferiria o direito à propriedade.

Também é importante notar que no tratamento da questão do registro geral, praticamente não se fez referência à localização ou especificação dos imóveis, sendo a preocupação central do legislador o contrato da alienação e o contrato da garantia, conforme alterações do Decreto 169-A de 1890. As consequências desse desencontro não seriam mais resolvidas, seriam verificadas em outros tantos lugares e, ainda dois séculos depois, seus efeitos seriam sentidos como apontou Brandão (2003, p.15-16), "no Brasil e na maioria dos países do mundo, de uma maneira geral não há uma interligação entre os sistemas de cadastro e de registro, que se constituem em geral em instituições distintas. Normalmente o cadastro é realizado para fins fiscais, e o registro legal é feito sem informações cadastrais".

Apenas com o Decreto de instituição do Registro Torrens é que serão dirigidas as primeiras preocupações com a localização correta e a especificação dos imóveis, tais como altitudes relativas de cada estação de instrumento e a conformação altimétrica ou orográfica aproximativa dos terrenos; construções existentes com indicação e seus usos, cercas e muros, situação das águas no imóvel, vias, rumos, acidentes, perfil geológico, dentre outras questões e, as escalas definidas em função do tamanho da propriedade. Por fim, a norma estabelecia a responsabilidade de engenheiros ou agrimensores na realização de tais atividades, porém, o registro era facultativo e a quantidade de imóveis que tiveram o seu registro nesses termos foi ínfima.

O Decreto que tratava do Registro Torrens foi revogado e as normas que apontavam para a maior identificação topográfica são abandonadas a seguir, a sua retomada ocorre com o Código de Processo Civil de 1939 que guardava capítulo específico para o assunto, depois, em 1973 com a Lei de Registros Públicos. Ocorre que, a utilização do Torrens continua a não ser considerada a forma mais utilizada de registro de imóveis e, o próprio instituto padece de problemas jurídicos estruturais, pois, ainda que houvesse a previsão juris et de jure para esse tipo de registro, o que significa dizer, a presunção absoluta de veracidade daquela informação e até mais que isso, a ideia de perenidade, mesmo diante de todas as transformações sociais, é de se saber que dada a natureza da mutabilidade do Direito e, portanto, da sua adequação social e mesmo técnica às novas realidades, tal pretensão não seria alcançada e, ainda que mais seguro, esse registro estaria adstrito às novas condições assim como o restante das normas registrais inscritas na presunção juris tantum, o que significa dizer, na presunção relativa de veracidade. Dessa forma, a revogabilidade da norma se deu, como se pode notar nas mudanças no seu escopo, sendo revisada e reeditada e a previsão inusual de que: "O imóvel registrado para 
os efeitos do Decreto $n .451-B$, de 31.5.1890, ficará para sempre sujeito ao regime deste regulamento" não pode ser reconhecida, ainda que tenha sido reincorporada nas novas legislações, inclusive na Lei de Registros Públicos, em capítulo específico sobre o tema. O Torrens, ainda que pretenda, não dispensa, como os demais registros, certa ficção apenas aparentemente mais precisa.

Em 1917, com a entrada em vigor do Código Civil, buscou-se consolidar o regime proprietário proposto em meados do século anterior, identificado na aquisição de bens imóveis pela via da transcrição de títulos, ainda que do ponto de vista da estruturação proprietária outras formas de aquisição fossem admitidas, como a usucapião, a acessão e o direito hereditário. Ocorre que a distância entre cadastro e registro foi mantida, bem como a separação entre posse, uso e propriedade, o que agudizou, com as novas normas apartadas da realidade brasileira, o quadro de desigualdade, injustiça e imprecisão territorial. A segurança jurídica derivava do poder de fazer o Estado reconhecer algo como de alguém. Dado que parte expressiva da população não acessava os recursos da legitimação, poucos foram os que puderam se apropriar nos termos da lei, de terras no regime instaurado.

Durante todo o decorrer do século XX, a questão referente à aquisição e ao registro de bens imóveis só se complexificou. Com a urbanização, a industrialização e o aumento demográfico, novas formas de parcelamento surgiram, bem como, foi alterada a própria estruturação dos regimes condominiais e a preocupação com os bens públicos sugeriu a necessidade de revisão dos direitos patrimoniais privados. Logo na década de 30, os regimes de loteamento, as demarcações de áreas ambientais já estabeleciam a necessidade de se agregarem aos registros mais informações sobre os bens. Na década seguinte, as preocupações com os bens públicos e as desapropriações também se fazem presentes e, daí em diante, muitas legislações sobre imóveis vão se estabelecer, tanto com preocupações sobre o cadastramento, como na forma de proteção ou utilização dos bens, como por exemplo, com legislações como o Estatuto da Terra, o Sistema Financeiro de Habitação e o Código Florestal.

Ao longo de todo esse período, mesmo diante das novas possibilidades de gestão e controle do território brasileiro via Direito e Cartografia, mantiveram-se presentes os termos da instituição do privilégio colonial dos registros e da entrega de terras àqueles que tinham acesso ao aparato estatal, bem como a despreocupação sobre o importante casamento entre o conhecimento sobre o território e a construção e aplicação normativa. As confusões e imprecisões geradas pelas bases do sistema proprietário e registral, do sistema sesmarial, do registro do vigário, da ausência de critérios universais de medição, especificação, localização e da própria especificidade de ocupação originária do território, alimentaram e aprofundaram, ao longo de todo o século XX, as relações conflituosas sobre a terra, negando posses legítimas e tradicionais, despejando possuidores com direito de permanência e subsidiando a indústria das fraudes territoriais que usavam e superavam os aparatos cartoriais, infiltravam-se nas administrações locais e supralocais e, ainda, ganhavam ares de veracidade com as decisões judiciais.

As novas normas que pretendiam algumas mudanças, ainda que tocassem eventualmente, em pontos sensíveis dos problemas cultivados durante toda a história anterior da formalização das terras, não eram e não foram capazes de alterar comportamentos que estavam e ainda estão fundados na mentalidade ancorada nos privilégios. Assim, mesmo diante das importantes legislações da década de 1970, a criação do Sistema Nacional de Cadastro Rural, a Lei de Registros Públicos e a Lei de Parcelamento do Solo Urbano, a reestruturação do sistema se dará de forma lenta e não necessariamente caminhará para a resolução dos problemas, inclusive, acabou por fundar, em muitos casos, um conjunto de "novas irregularidades fundiárias" no quadro territorial brasileiro, agravado pelos entendimentos judiciais.

\subsection{As bases da instituição do sistema jurídico registral do século XX: latifúndio e Reforma Agrária}

Recuperando o modelo registral adotado pelo Código Civil de 1916, como se apontou, esse teve por finalidade consolidar as propriedades já tituladas, na vigência da Lei de Terras, com base em documentos eivados de imprecisões quanto à localização e dimensão das propriedades. Esse modelo de registro não exige 
nenhum elemento cadastral que descreva objetivamente o imóvel, pois apenas se baseia nos documentos que abstraem a situações concretas e, por isso, acaba por convalidá-los e dar aparência legal a toda sorte de ilegalidades e violências ocorridas na constituição dessas propriedades por posses, por títulos de sesmarias adulterados nas sucessivas transcrições, ou por meio de sentenças do Poder Judiciário em ações que discutiram a sucessão hereditária dessas terras.

A nova reorganização dos registros de imóveis será realizada somente em 1973, mantendo elementos centrais da conformação dos registros anteriores, unificando várias espécies de registros e delimitando mais pormenorizadamente os itens relativos à especialização do imóvel.

As alterações legislativas ocorridas desde 1850 sobre o regime jurídico das terras públicas e privadas, no Brasil, são feitas em diferentes regimes políticos, mas todas tem como núcleo intocável a proteção da propriedade privada de caráter absoluto, o que gerou inúmeros conflitos pela posse e uso da terra, no campo e nas cidades brasileiras, desde o período imperial.

A Constituição Federal de 1988 ao fechar o ciclo de governos ditatoriais e ao preconizar a diminuição das desigualdades materiais da sociedade brasileira e da redução da pobreza (COMPARATO, 1998), pela via do direito, pela atuação do Judiciário e por políticas públicas do Estado Social Democrático de Direito, mesmo diante da constatação dos limites e interesses expostos na Assembleia Nacional Constituinte, pelos congressistas defensores comprometidos com o status quo (FACHIN, 1987), enfrentou a questão fundiária, e previu instrumentos jurídicos das Reformas Agrária e Urbana, com a finalidade de ajustar o uso e fruição da propriedade aos interesses da sociedade e não apenas de um único proprietário. Para fundamentar essa política fundiária, o art. $5^{\circ}$, inciso XXIII da Constituição estabeleceu como um dos princípios fundamentais da ordem jurídica nacional "a função social da propriedade", que altera a determinação do conteúdo proprietário, compreendendo a importância de centros de interesse extraproprietários (TEPEDINO, 1999), coletivos e difusos.

O caráter determinantemente econômico desse objetivo fundante a ser alcançado pela República brasileira atinge as relações privadas no âmbito do mercado, pois exige o livre acesso de todos aos bens de valor econômico socialmente produzidos, entre eles a terra apta à produção agrícola e para a moradia. Por meio da Reforma Agrária, o Estado brasileiro pode intervir na economia e na propriedade privada, para promover a redução de uma desigualdade material essencial que se verifica entre proprietários e não-proprietários, cuja condição econômica e cultural coloca sua sobrevivência física e social na dependência ao acesso à terra, do trabalho e da produção agrícola, acesso esse que se encontra inviabilizado nos termos atuais da economia brasileira e na ausência de informações publicizadas que possam esclarecer os limites dos modelos territoriais adotados até então.

A intervenção no domínio econômico do mercado e no domínio específico da economia agrária exigiu, por evidente, alterações nas regras referentes ao regime jurídico que regula o exercício das terras apropriadas por particulares no meio rural. A Constituição assegura o direito individual à propriedade, mas admite o controle estatal sobre as faculdades que compõem o conteúdo jurídico desse direito subjetivo de natureza patrimonial e privada, condicionando seu exercício ao cumprimento de obrigações jurídicas previstas nos arts. $5^{\circ}$, XXIII, e 186. Assim, os sujeitos privados estão obrigados ao cumprimento do dever social de proprietário que não pode significar lesão a terceiros. As garantias ligadas normalmente à propriedade, notadamente a de exclusão das pretensões possessórias de outrem, devem ser afastadas quando eivadas de esvaziamento de legitimidade à luz da avaliação sobre a função social. Como foi adequadamente salientado na doutrina alemã contemporânea, a norma de vinculação social da propriedade não diz respeito, tão só, ao uso do bem, mas à própria essência do direito. Quem não cumpre a função social da propriedade perde as garantias, judiciais e extrajudiciais, de proteção da posse (COMPARATO, 1998).

Assim, o exercício do direito do proprietário continua apoiado no dado subjetivo e abstrato, sob a forma de direito subjetivo, e inclui um dado objetivo social, que é expresso em determinadas obrigações. Sob esta fórmula constitucional da propriedade evidenciam-se duas vertentes de um Estado de Direito: a clássica liberal, que reconhece sujeitos como detentores de direitos, entre eles o de propriedade; e a de um estado social democrático, comprometido em buscar a igualdade material. Apoiada nessa dualidade de vertentes políticas, uma marcadamente liberal e outra de cunho social-democrático o Estado brasileiro não parece ter tido força 
suficiente para eliminar os conflitos pela posse e uso da terra no campo brasileiro, o que denuncia que algo na arquitetura constitucional não conseguiu alterar as relações sociais entre proprietários e trabalhadores rurais no Brasil e, consequentemente, alterar o direito e a orientação conceitual que determina as decisões do Poder Judiciário.

Na questão relativa ao acesso e uso de terra rural, essas limitações decorrem, sobretudo, da inexistência de previsão constitucional a qualquer limite à apropriação privada e uso da terra produtiva. Nesse aspecto foi resguardada uma liberdade de apropriação privada ilimitada, é bem verdade condicionada à observância que permite a existência de latifúndios inatingíveis pela desapropriação por interesse social, para fins de Reforma Agrária, desde que cumpra sua função social, ou melhor, segundo o art. $5^{\circ}$, XXIII, ou que sejam, simplesmente, produtivas, conforme art. 186, da Constituição Federal, e da legislação especial que regula a desapropriação por interesse social para fins de reforma agrária.

Dadas as dificuldades em estabelecer limites aos privilégios já descritos, soma-se a precariedade dos sistemas que invisibilizam o roubo de terras públicas, no campo e na cidade, e que permitem, via medidas declaratórias de indicações territoriais em cadastros oficiais e posterior regularização fundiária, com marcos temporais sempre postergados, estabelece a cultura dos "fatos consumados" para uns, enquanto estabelece rígidas punições a possuidores legítimos que recorrentemente sofrem processos violentos de despejo por particulares ou pelo próprio Estado. Esse estado de coisas pode ser vislumbrado na manutenção dos termos de uma legislação registral que pode ser considerada obsoleta, dados os fundamentos que a constituíram e, as leis mais recentes de regularização como aconteceu com as definições do Código Florestal de 2012 e com a Lei de Regularização Fundiária de 2017. Ambas acabaram por não enfrentar os problemas causados no passado distante e recente e, em grande medida, podem acentuar ilegitimidades conhecidas e recorrentes, novamente distorcendo as relações territoriais que podem ser consideradas importantes para o assentamento de uma realidade territorial condizente com princípios civilizatórios estabelecidos no texto constitucional.

Ainda que a cartografia permita melhoramentos no conhecimento sobre o território brasileiro, sem dúvida, o olhar sobre o passado permite o reconhecimento sobre as raízes que fundam os problemas contemporâneos, sobre as imprecisões e sobre um discurso que não encontrava e não encontra na realidade os elementos hábeis à sua efetiva realização.

O direito apenas muito recentemente se abre ao diálogo com outras áreas de modo mais efetivo e, nesse encontro, incorpora a publicização como elemento essencial da concretização dos valores esboçados na Constituição. O mapeamento e os cadastros são elementos sensíveis e essenciais nesse processo, pois visibilizam decisões e encontram na concretude do cotidiano das questões territoriais as escolhas normativas e as suas interpretações nos âmbitos administrativo e judicial de sua aplicação. Retirar os véus que encobrem as equívocas decisões passadas e estreitar os vínculos de duas disciplinas que caminham juntas, pode potencializar os acertos para novos modos de tratar a apropriação, os usos e o respeito às gentes desse imenso território.

\section{A AUSÊNCIA DO MAPEAMENTO DE REFERÊNCIA E O PROBLEMA DA DEMARCAÇÃO DE TERRAS NO BRASIL}

A primeira fase da evolução da ocupação e da legislação territorial brasileira é demarcada pela política de um Estado colonial que detinha o domínio de todo território brasileiro e tinha por finalidade atribuir a propriedade privada aos grupos que sustentavam o governo monárquico. Foi nesse período que iniciou a história do mapeamento do território brasileiro com as primeiras observações astronômicas. Estas observações se deram no Rio de Janeiro e em São Paulo, no período de 1781 a 1795 (GESTEIRA, 2015). Na segunda fase, Império, há uma espécie de hiato na destinação de terras públicas a particulares, o que levou a uma reação da economia agrária brasileira a buscar uma expansão das propriedades de terras por meio do instituto jurídico da posse. $\mathrm{O}$ momento seguinte coincide com a primeira tentativa de modernização (leia-se modernidade jurídica baseada na propriedade privada individual) de modo a fechar (enclosure) as terras públicas para destiná-las apenas aos súditos com acesso a burocracia estatal (Lei de Terras de 1850). O Decreto 1318 de 1854, regulamentador dessa lei, determinou a medição de terras e criou a figura do juiz comissário de medições. Esses processos, no entanto, ocorreram sem que houvesse uma particular preocupação com os aspectos 
cartográficos para a demarcação precisa dos limites das terras, isto é, a preocupação era somente com os limites externos da colônia e do Império e não entre domínios e posses de súditos.

Nestes mais de 300 anos, a ocupação aconteceu sem que o território brasileiro fosse devidamente cartografado e, portanto, conhecido. Quase 100 anos depois das primeiras observações astronômicas é que houve uma tentativa de mapear o Brasil com base em critérios técnico-científicos. Isto se deu em 1864 com a criação da Comissão da Carta Geral do Império, cuja missão era estabelecer um referencial geodésico por triangulação e confeccionar 42 folhas para todo o território brasileiro. Em 1871 estavam prontas 31 folhas (MENEZES, 2007). A Carta do Império do Brasil (Figura 1) foi publicada na escala 1:3.710.220, em função de sua baixa acurácia, e foi apresentada na Exposição Nacional de Viena em 1875 e na Exposição Universal da Filadélfia de 1876.

Figura 1 - Carta do Império do Brasil.

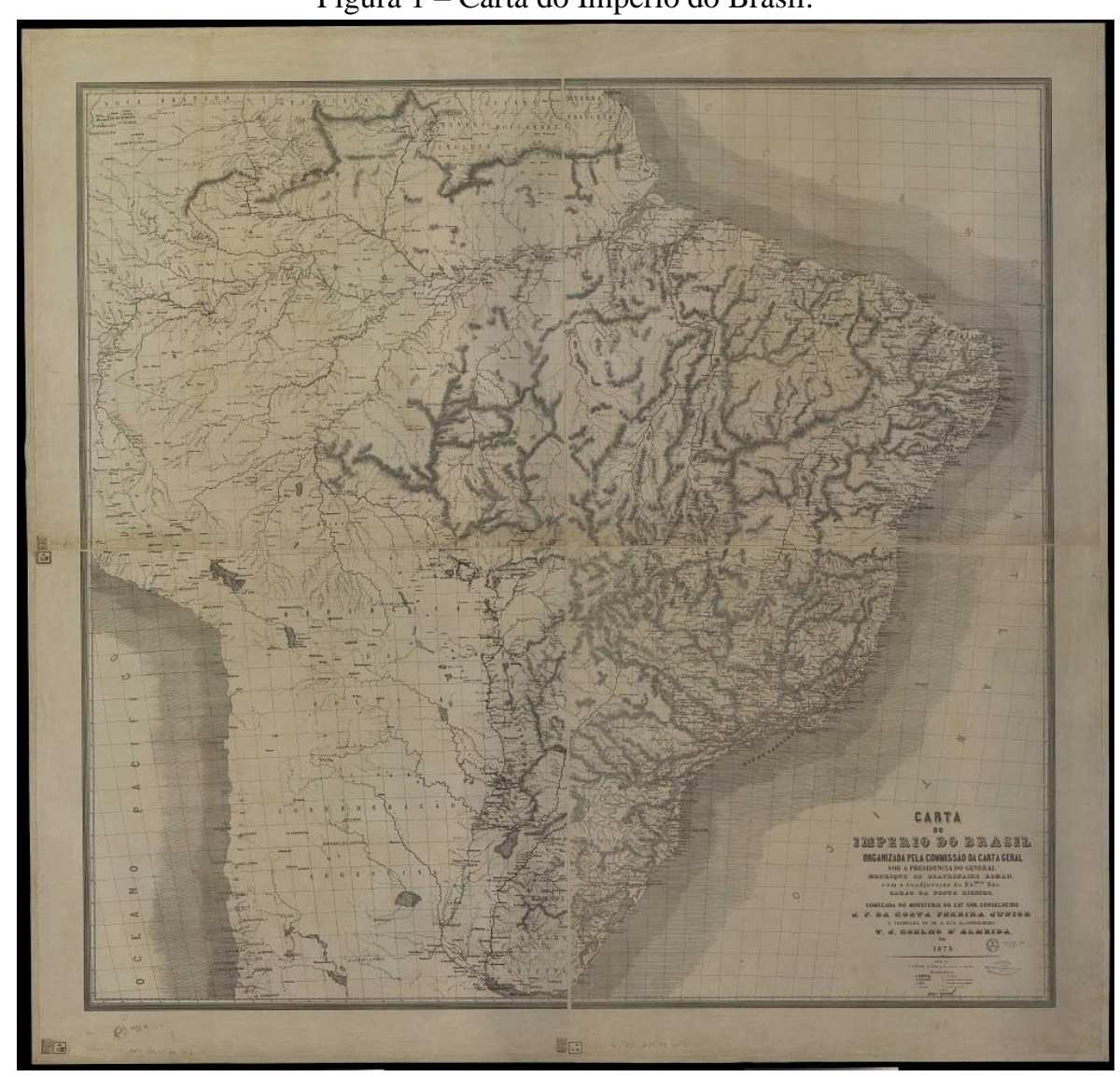

Fonte: Ponte Ribeiro, Duarte da Ponte Ribeiro, Barão de (1873).

Os primeiros passos no sentido de considerar a demarcação precisa das propriedades se deram no período republicano. A Constituição Federal de 1891 transferiu para os Estados o domínio das terras devolutas. Em 1901, o Estado Maior elaborou o projeto intitulado "A Carta Geral do Brasil" com o objetivo de preparar um mapa de referência para o Brasil a partir de operações geodésicas, astronômicas, topográficas e cartográficas. Este projeto estabeleceu os processos de levantamento, os sistemas de projeção, as escalas e os formatos das folhas para a Carta Geral do Brasil (BERNARDINO, 2012). A execução deste projeto iniciou em 1903 com a instalação da Comissão da Carta Geral, em Porto Alegre - RS (DSG, 2014; IESCHECK et al., 2014). Os resultados, no entanto, ficaram muito aquém do planejado. Estava previsto a realização de 3.000 folhas na escala 1:100.000, mas foram confeccionadas apenas 53 folhas nesta escala, além do mapeamento das principais cidades na escala 1:25.000 $\left(4.000 \mathrm{~km}^{2}\right)$. Diversos problemas ocorridos a partir de 1922 impediram que os últimos anos de atividade da Comissão da Carta Geral se dessem com normalidade e, em 1930, praticamente todos os trabalhos foram encerrados (DSG, 2014).

Apesar da ausência de mapeamento topográfico em escalas grandes, com o Código Civil de 1916 passou-se a admitir a aquisição de propriedade pela transcrição de contrato de compra e venda no Registro de 
Imóveis. Somente em 1922 o território brasileiro foi completamente mapeado, com a publicação da Carta do Brasil ao Milionésimo que compreendia um total de 50 folhas na escala 1:1.000.000 (ARCHELA; ARCHELA, 2008). O Código de Processo Civil de 1939 introduziu o sistema de Registro Torrens e possibilitou a aquisição e a perda da terra.

A Constituição Federal de 1946 definiu as bases para o novo sistema jurídico-agrário, estabelecendo o uso da propriedade para o bem estar social. O Estatuto da Terra (Lei 4.504 de 1964) criou o Instituto Brasileiro de Reforma Agrária (IBRA) e o Instituto Nacional de Desenvolvimento Agrário (INDA) e, em 1966, foi instituído o Plano Nacional de Reforma Agrária. Em 1967, por meio do decreto-lei ${ }^{\circ} 243$ que fixa as diretrizes e bases da cartografia brasileira, foi criada a Comissão de Cartografia (COCAR) e em 1970 o Instituto Nacional de Reforma Agrária (INCRA). Já, em 1972, o decreto n 5868 determinou a criação do Sistema Nacional de Cadastro Rural (SNCR), com o objetivo de promover a integração e sistematização da coleta, pesquisa e tratamento de dados e informações sobre o uso e posse da terra. O SNCR foi regulamentado em 1973 pelo decreto 72.106, e no mesmo ano foi aprovada a Lei de Registros Públicos (Lei 6015).

Contudo, apenas em 1978 foi aprovado pelo Governo Federal o Plano Cartográfico Nacional, que propunha executar a cartografia sistemática em escalas 1:100.000 e 1:250.000 e deveria ser concluído até 1985 (ARCHELA; ARCHELA, 2008). O decreto $\mathrm{n}^{\circ} 89.817$ de 1984 estabeleceu as Instruções Reguladoras das Normas Técnicas da Cartografia Nacional, com o objetivo de estabelecer procedimentos e padrões mínimos a serem adotados no desenvolvimento das atividades cartográficas. Em 1985, foi aprovado o novo Plano Nacional de Reforma Agrária (PNRA), cuja execução ficou sob a responsabilidade do INCRA, por meio do decreto $\mathrm{n}^{\circ} 91.766$.

A Constituição Federal de 1988, além de enfrentar a questão fundiária estabelecendo "a função social da propriedade", determina que a organização e a manutenção dos serviços oficiais de Cartografia seja uma competência da União (artigo 21) bem como a legislação sobre o sistema cartográfico nacional (artigo 22).

A COCAR foi desativada em 1990 e reativada em 1994, com a denominação de Comissão Nacional de Cartografia (CONCAR), com as atribuições de assessorar o Ministro de Estado na supervisão do Sistema Cartográfico Nacional (SCN) e coordenar a execução da Política Cartográfica Nacional. Em 1996, por meio de decreto, foi nomeado o ministro de Estado Extraordinário de Política Fundiária, e em 1999 foi criado o Ministério da Política Fundiária e do Desenvolvimento Agrário, pela Medida Provisória 1.999-1. O Decreto 6.666 de 2008 (CONCAR, 2010) instituiu a Infraestrutura Nacional de Dados Espaciais (INDE), com o objetivo de promover o adequado ordenamento na geração, no armazenamento, no acesso, no compartilhamento, na disseminação e no uso dos dados geoespaciais.

Nota-se, portanto, da Colônia à República, o descompasso cronológico entre a ocupação do território - suas legislações, e o conhecimento do território - seu mapeamento. O Quadro 1 apresenta a linha do tempo com os principais marcos relacionados ao mapeamento topográfico de referência e à demarcação de terras no Brasil. 
Quadro 1 - Relação cronológica jurídico-cartográfica brasileira.

(continua)

\begin{tabular}{|c|c|c|}
\hline \multirow{2}{*}{\multicolumn{2}{|c|}{ CARTOGRAFIA }} & \multirow[b]{2}{*}{ DIREITO } \\
\hline & & \\
\hline Séculos XVI, XVII e XVIII & & Capitanias hereditárias e sesmarias \\
\hline 1695 & & $\begin{array}{l}\text { Carta Régia: tentativa de controle sobre a } \\
\text { apropriação da situação territorial da } \\
\text { colônia }\end{array}$ \\
\hline 1781 a 1795 & $\begin{array}{l}\text { Primeiras observações astronômicas } \\
\text { (Rio de Janeiro e São Paulo) }\end{array}$ & \\
\hline \multicolumn{3}{|l|}{ IMPÉRIO } \\
\hline 1822 & & $\begin{array}{l}\text { Constituição do Império, fim do sistema } \\
\text { de sesmarias e instituição do direito à } \\
\text { propriedade pelo reconhecimento da } \\
\text { posse da terra }\end{array}$ \\
\hline 1824 & & Instituição do direito à propriedade \\
\hline 1850 & & $\begin{array}{l}\text { Lei } 601 \text { - Lei de Terras: acesso à } \\
\text { propriedade pelo sistema de compra e } \\
\text { venda e redefine o conceito de terras } \\
\text { devolutas }\end{array}$ \\
\hline 1854 & & $\begin{array}{l}\text { Decreto 1318: regulamentação da Lei de } \\
\text { Terras e criação da Repartição Geral de } \\
\text { Terras Públicas }\end{array}$ \\
\hline 1864 & $\begin{array}{l}\text { Criação da Comissão da Carta Geral do } \\
\text { Império }\end{array}$ & \\
\hline 1871 & $\begin{array}{l}\text { Publicação da Carta do Império do } \\
\text { Brasil (escala 1:3.710.220) }\end{array}$ & \\
\hline 1875 & $\begin{array}{l}\text { Exposição Nacional da Carta do } \\
\text { Império do Brasil }\end{array}$ & \\
\hline 1876 & $\begin{array}{l}\text { Exposição Universal na Filadélfia da } \\
\text { Carta do Império do Brasil }\end{array}$ & \\
\hline \multicolumn{3}{|l|}{ REPÚBLICA } \\
\hline 1891 & & $\begin{array}{l}\text { Constituição de 1891: transfere aos } \\
\text { estados as terras devolutas }\end{array}$ \\
\hline 1903 & $\begin{array}{l}\text { Criação da Comissão da Carta Geral do } \\
\text { Brasil }\end{array}$ & \\
\hline 1916 & & $\begin{array}{l}\text { Código civil: admite a aquisição pela } \\
\text { transcrição de contrato de compra e } \\
\text { venda no Registro de Imóveis }\end{array}$ \\
\hline 1922 & $\begin{array}{l}\text { Substituição da Comissão da Carta } \\
\text { Geral pelo Serviço Geográfico do } \\
\text { Exército e publicação da Carta do } \\
\text { Brasil ao Milionésimo }\end{array}$ & \\
\hline 1934 & & $\begin{array}{l}\text { Constituição de 1934: institui a } \\
\text { desapropriação por necessidade de } \\
\text { utilidade pública }\end{array}$ \\
\hline 1936 & Criação do IBGE & \\
\hline 1937 & $\begin{array}{l}\text { Primeiro projeto do IBGE: } \\
\text { determinação das coordenadas das } \\
\text { cidades e vilas }\end{array}$ & \\
\hline 1939 & & $\begin{array}{l}\text { Código de Processo Civil: admite a } \\
\text { aquisição e perda da terra e introduz o } \\
\text { Registro Torrens }\end{array}$ \\
\hline \multirow[t]{2}{*}{1946} & $\begin{array}{l}\text { Início do mapeamento do Vale do São } \\
\text { Francisco e do território da Bahia } \\
\text { (escala 1:250.000) }\end{array}$ & $\begin{array}{l}\text { Decreto-lei 9760: administração das } \\
\text { terras e bens públicos em geral a cargo do } \\
\text { Serviço de Patrimônio da União }\end{array}$ \\
\hline & & $\begin{array}{l}\text { Constituição de 1946: bases para o novo } \\
\text { Sistema jurídico-agrário - artigo 147: uso } \\
\text { da propriedade para o bem estar social }\end{array}$ \\
\hline 1964 & & $\begin{array}{l}\text { Lei 4.504: edita o Estatuto da Terra e cria } \\
\text { o Instituto Brasileiro de Reforma Agrária } \\
\text { (IBRA) e o Instituto Nacional de } \\
\text { Desenvolvimento Agrário (INDA) }\end{array}$ \\
\hline 1966 & & $\begin{array}{l}\text { Decreto 59.456: institui o Plano Nacional } \\
\text { de Reforma Agrária }\end{array}$ \\
\hline 1967 & $\begin{array}{l}\text { Decreto-Lei } 243 \text { - Diretrizes e Bases da } \\
\text { Cartografia Brasileira: criação da } \\
\text { Comissão Nacional de Cartografia } \\
\text { (COCAR) }\end{array}$ & \\
\hline 1970 & Criação do INCRA & \\
\hline
\end{tabular}




\begin{tabular}{|c|c|c|}
\hline REPÚBLICA & & (conclusao \\
\hline 1972 & & $\begin{array}{l}\text { Decreto 5868: determinou a criação do } \\
\text { Sistema Nacional de Cadastro Rural } \\
\text { (SNCR) }\end{array}$ \\
\hline 1973 & & $\begin{array}{l}\text { Decreto 72.106: regulamentação do } \\
\text { SNCR } \\
\text { Lei 6015: Lei de Registros Públicos }\end{array}$ \\
\hline 1978 & $\begin{array}{l}\text { Aprovação do Plano Cartográfico } \\
\text { Nacional }\end{array}$ & \\
\hline 1984 & $\begin{array}{l}\text { Decreto } \mathrm{n}^{\circ} 89.817: \text { Instruções } \\
\text { Reguladoras das Normas Técnicas da } \\
\text { Cartografia Nacional }\end{array}$ & \\
\hline 1985 & & $\begin{array}{l}\text { Decreto } n^{\circ} \text { 91.766: aprova o novo Plano } \\
\text { Nacional de Reforma Agrária }\end{array}$ \\
\hline 1988 & $\begin{array}{l}\text { Constituição Federal de 1988: a } \\
\text { Cartografia é uma competência da } \\
\text { União }\end{array}$ & $\begin{array}{l}\text { Constituição Federal de 1988: } \\
\text { estabeleceu a função social da } \\
\text { propriedade }\end{array}$ \\
\hline 1990 & Desativação da COCAR & \\
\hline 1994 & $\begin{array}{l}\text { Reativação da Comissão Nacional de } \\
\text { Cartografia (CONCAR) }\end{array}$ & \\
\hline 1996 & & $\begin{array}{l}\text { Nomeação do ministro de Estado } \\
\text { Extraordinário de Política Fundiária }\end{array}$ \\
\hline 2000 & & $\begin{array}{l}\text { Criação do Ministério do } \\
\text { Desenvolvimento Agrário }\end{array}$ \\
\hline 2008 & $\begin{array}{l}\text { Decreto 6.666: institui a Infraestrutura } \\
\text { Nacional de Dados Espaciais (INDE) }\end{array}$ & \\
\hline
\end{tabular}

Fonte: Os autores (2020).

\section{DIAGNÓSTICO DA SITUAÇÃO ATUAL DO CADASTRO TERRITORIAL E SUA RELAÇÃO COM O MAPEAMENTO TOPOGRÁFICO SISTEMÁTICO}

A função do cadastro é coletar e disponibilizar informações gráficas e descritivas sobre as parcelas de um território, com base no levantamento dos seus limites (UNECE, 2005). No Brasil, a ausência de uma lei nacional de cadastro e de uma instituição que tenha como competência principal o estabelecimento de diretrizes para a sua elaboração fez com que este tenha se desenvolvido sem que haja uma integração entre os cadastros rurais e urbanos. Enquanto o cadastro rural foi estabelecido por lei (a lei 5868/72 determina a criação do Sistema Nacional de Cadastro Rural), sob a responsabilidade da administração federal, para os cadastros urbanos não há legislação específica e sua implementação é realizada pelas administrações municipais, geralmente para fins fiscais. Assim, ao longo do tempo, foram desenvolvidos cadastros rurais baseados exclusivamente em informações descritivas, uma vez que não se dispõe de uma cartografia sistemática em escala adequada, nem a instituição desses cadastros considerou a elaboração de uma base cartográfica como um dos seus elementos essenciais. O Quadro 2 resume a atual constituição dos principais cadastros rurais. Além desses, que visam cobrir toda a estrutura fundiária rural, existem os cadastros ambientais, de terras indígenas, de terras da União (que abrangem também imóveis urbanos).

Quadro 2 - Atual constituição dos principais cadastros rurais - SNCR - Sistema Nacional de Imóveis Rurais; CAFIR - Cadastro de Imóveis Rurais e CNIR - Cadastro Nacional de Imóveis Urbanos.

\begin{tabular}{|l|l|l|l|}
\hline & SNCR & CAFIR & CNIR \\
\hline administração & INCRA & $\begin{array}{l}\text { Receita } \\
\text { Federal }\end{array}$ & INCRA + Receita Federal \\
\hline dados descritivos & Sim & Sim & $\begin{array}{l}\text { Sim (em fase de compatibilização entre o SNCR e } \\
\text { CAFIR) }\end{array}$ \\
\hline base cartográfica & Não & Não & Não \\
\hline base geométrica (medição das parcelas) & Não & Não & $\begin{array}{l}\text { Possibilidade de utilização dos levantamentos } \\
\text { georreferenciados em atendimento à Lei 10.267/2001 }\end{array}$ \\
\hline
\end{tabular}

Fonte: Os autores (2020).

Quanto aos cadastros urbanos, pode-se afirmar que a maioria dos municípios segue a metodologia estabelecida pelo Projeto CIATA - Convênio de Incentivo ao Aperfeiçoamento Técnico - que foi implantado, 
de forma experimental (1973/74), pela Secretaria de Economia e Finanças do Ministério da Fazenda do Brasil, com recursos do Programa de Assistência Técnica - PRAT e, por meio do Serviço Federal de Processamento de Dados (SERPRO). Segundo Cunha et.al. (2019), de um modo geral, a metodologia utilizada pelo Projeto CIATA para o cadastro imobiliário urbano era composta de duas fases: Execução e Implantação. A fase de execução era constituída por 6 etapas: Setorização Fiscal, Levantamento Cadastral, Avaliação de Imóveis, Tratamento da Informação, Lançamento e Arte Final (planta quadra/logradouro), sendo que as 4 primeiras etapas eram realizadas diretamente pelo SERPRO e as duas últimas pela prefeitura, com orientação do SERPRO.

Com uma metodologia condizente com a tecnologia disponível na época, o Projeto CIATA previa a elaboração de plantas de quadra isoladas, cuja localização no perímetro urbano municipal era identificada através de uma Planta de Referência Cadastral. Nem sempre os municípios conseguiram elaborar a base cartográfica prevista, por isso muitos dispunham de um cadastro exclusivamente descritivo, baseado em informações obtidas a partir dos boletins de informações cadastrais. Com as possibilidades de informatização dos sistemas, municípios com melhores condições técnicas e econômicas procederam ao desenvolvimento de cadastros baseados em mapeamentos aerofotogramétricos. A realidade das desigualdades de um país de extensa dimensão territorial se reflete também nos cadastros atuais, onde podem ser encontrados poucos cadastros estruturados para atender a múltiplos fins, outros que buscam aplicar as facilidades das tecnologias para a implementação de bases cartográficas mais simples, que atendam a objetivos fiscais, e muitos que ainda não dispõem de informações gráficas para apoiar os seus sistemas cadastrais. Mais uma vez, a falta de mapeamento sistemático em escala compatível com o cadastro urbano dificulta a implantação de um cadastro que, de fato, sirva de base para o desenvolvimento de políticas públicas integradas.

O mapeamento topográfico sistemático, conforme planejado e executado na França por Colbert e Cassini, deve ser realizado com o estabelecimento de um Sistema Geodésico de Referência, tal como o Sistema Geodésico Brasileiro (SGB), e este deve ser materializado em marcos geodésicos. O conjunto de marcos geodésicos deve ser conectado em uma rede. É a conformação em rede e, consequentemente, a conexão matemática entre todos os marcos geodésicos que garante a uniformidade da qualidade posicional em todo o território mapeado. A uniformidade e a homogeneidade da rede geodésica possibilitam a realização do mapeamento em escalas grandes com alta acurácia e precisão. Este foi um dos grandes avanços que o Mapa da França de Cassini proporcionou aos mapeamentos topográficos, e que também possibilita que o cadastro territorial seja construído com qualidade posicional uniforme em todo o território nacional.

Quando o cadastro territorial é realizado com levantamentos terrestres ou aerofotogramétricos locais, mesmo quando amarrados ao SGB, contudo com resultados independentes e particulares àqueles determinados locais, tem-se em todo o país um conjunto de levantamentos e representações cadastrais geometricamente independentes. Permitindo-se o uso de linguagem coloquial, é possível imaginar os diversos cadastramentos em diferentes regiões do país, como uma "colcha de retalhos". Cada um destes "retalhos" está em diferentes níveis de detalhamento e de qualidade posicional.

A interdependência entre o cadastro territorial e o mapeamento topográfico sistemático deve existir quando se objetiva que a homogeneidade nos padrões que determinam as características esperadas para os resultados alcançados tanto para o cadastro como para o mapeamento topográfico sistemático seja alcançada em todo o território nacional. Assim, o que e como cadastrar, e o que e como mapear, e com que nível de qualidade deveria ser semelhante em qualquer lugar, em qualquer município de nosso país.

\section{CONSIDERAÇÕES FINAIS E PESQUISAS FUTURAS}

Os estudos relatados neste artigo tiveram o intuito de estabelecer um projeto de pesquisa que busca entender a situação atual da Cartografia Topográfica e do Cadastro Territorial, e suas relações com a legislação que determina a ordenação territorial no Brasil. O trabalho interdisciplinar aqui desenvolvido buscou visibilizar os fundamentos e os percursos seguidos na constituição da história narrada pela Cartografia e pelo Direito, especialmente quando as duas disciplinas se encontram para fundar um modelo de estruturação da terra. A importância do diálogo das áreas de conhecimento que tanto podem decifrar e auxiliar na interpretação do que 
existe e na construção de novas realidades tem por objetivo justamente compreender o que aconteceu nos últimos séculos para que o sistema apresentasse contemporaneamente as suas características, com os avanços e com os limites que ao serem identificados e analisados podem dar suporte a novas respostas para velhas e novas perguntas. Assim, é nesse sentido que se evidenciam acertos e falhas, decisões e silêncios sobre os fundamentos e o modo de operação do sistema de resolução das questões territoriais que dizem respeito tanto à construção de políticas públicas como às mais variadas respostas a grupos, comunidades e indivíduos, no que diz respeito aos territórios urbanos, rurais, tradicionais e ambientais.

A leitura de todas as situações não pretendeu apontar diretamente leituras valorativas acerca das constatações realizadas e, justamente pela pretensão estabelecida desde o início, os estudos também não procuraram reiterar justificações tradicionais. As evidentes contradições expostas nos fundamentos e desdobramentos do modo adotado pelo Brasil na estrutura territorial foram descritas, inclusive por se compreender que a visibilização dos problemas pode auxiliar na possibilidade de refundação dos seus sentidos a partir de uma leitura crítica dos modos como foram implementadas.

Ainda que a desigualdade e a injustiça territorial no Brasil sejam evidentes e tenham sido, em alguma medida, reforçadas pelas bases adotadas, nas contradições e nas frestas deixadas por essas duas grandes áreas, Cartografia e Direito, é possível dizer que ambas também permitem espaços de revisão e de realização de outras práticas. Entende-se que o conhecimento sobre o território significava e significa poder sobre a definição da vida da população e da estruturação dos espaços, e o aperfeiçoamento da leitura das questões territoriais, o que também permite que os instrumentos contemporâneos como os cadastros territoriais consignem a diversidade de temas que compõem a representação, a leitura analítica da terra e a pluralidade de políticas públicas que podem incidir sobre novas realidades territoriais. Mas, as análises sobre essas questões foram deixadas para a continuidade dos estudos e análises.

Por ora, pretendeu-se aqui rememorar o percurso histórico. No Brasil, a colonização plantou os elementos fundantes das tensões que iriam produzir um imenso território em disputa. A invasão por novas noções de sociedade se perfez em cada luta concreta por manutenção, sobrevivência, resistência e vida por e na terra. As querelas que atravessaram o tempo encontram raízes profundas no projeto colonizador e, portanto, na situação mais concreta que caracteriza as variadas situações de ocupação da terra e, ainda, nas construções descritivas, narrativas, ilustrativas e representativas que figuraram e figuram no imaginário popular, nos discursos de naturalização das assimetrias e em toda ordem de constituição de novos poderes que justificaram e justificam a injustiça territorial, em grande medida sustentada nos aparatos legitimadores do Direito e da Cartografia.

De fato, o conhecimento sobre a terra, sobre os territórios, ambientes e gentes é significativo na constituição dos poderes, na construção das políticas, na interpretação sobre a sociedade e na intervenção da realidade. No Brasil foram forjadas as bases de constituição dos sistemas que, muitas vezes imprecisos e irreais, constituíram legitimidade. Nem por isso se pretendeu, na depuração das inconsistências ou das injustiças, negar a importância e os avanços decorrentes das construções técnico-sociais e político-tecnológicas dessas matérias.

O que se constatou é que de algum modo, dada a situação geral desde a colonização, era premente constituir o sistema geral da administração de terras e, dada a necessidade de produção das oficialidades, prescreveu-se um sistema registral, com o mapeamento topográfico e a agrimensura. Porém, é só no século XX que se dá início a pretensão de planejamento territorial e da estruturação de sistemas e de cadastros e da formulação jurídica de ordenação territorial que superava a mera defesa dos interesses territoriais de cunho privatista. Para decifrar os aspectos contemporâneos do sistema territorial brasileiro, percorreu-se a trajetória da Cartografia e do Direito no Brasil o que significou, portanto, dentre outras questões, ver identificadas: as premissas desse sistema conjugado; o histórico, as bases, os percursos e o contexto em que essa Cartografia e esse Direito foram propostos como modelo de pensamento; as inconsistências, as ausências, as impossibilidades diante das condições de realização de um sistema jurídico-cartográfico; a organização do estado e da política pública de terras; as institucionalidades constituídas com o fim de realizar os estudos e levantamentos territoriais brasileiros; as regras dos sistemas; e os resultados, as consequências do que se produziu até o século XXI.

Diante do panorama histórico jurídico-cartográfico-cadastral estabelecido sobre as primeiras análises 
dispostas neste artigo, vislumbra-se a leitura sobre a contemporaneidade e, por isso, a continuidade do projeto de pesquisa que se dará em três eixos de análise. Elencam-se, assim, os seguintes desafios futuros de pesquisa:

a) A incorporação das complexidades e das ausências sentidas nas questões jurídicocartográficas-cadastrais. Este eixo está relacionado às questões de sobreposições, especialmente aquelas de caráter ambiental sobre os territórios, urbanos e rurais, e visa propor soluções adequadas, pertinentes e razoáveis que respondam as seguintes questões:

(i) Quais as consequências da ausência de mapeamento e de cadastro para a sociedade brasileira?

(ii) $\mathrm{O}$ cadastro contempla os direitos, restrições e responsabilidades existentes entre pessoa e terra?

(iii) Como viabilizar essa condição?

b) Compreender os significados de cartografar, cadastrar, planejar e regular a terra na perspectiva da leitura sobre a estruturação dessas atividades no âmbito do Estado e de suas instituições. O que significa dizer, que há necessidade de se compreender o planejamento territorial, a infraestrutura de dados e informações, e a gestão de dados territoriais considerando, inclusive, as propostas já realizadas, tal como o Sistema Nacional de Gestão de Informações Territoriais (SINTER), a questão tributária, a publicização de dados, dentre outras questões da própria organização contemporâneo do tratamento de informações territoriais;

c) "De costas para o Brasil: entre ausências e sobras", diz respeito ao terceiro eixo de análise voltado à compreensão sobre o que significou e significa a importação de modelos e soluções jurídico-cadastrais-cartográficas e as consequências dessas assimilações no histórico da estrutura de gestão fundiária brasileira. Buscar-se-á, a possibilidade de outras proposições de viés decolonial, autênticas que representem mais concretamente as possibilidades de planejamento, de gestão e de instrumentos que correspondam à realidade brasileira e às suas complexidades. Nesse sentido, pretende-se realizar análises comparativas de modelos latinoamericanos e também a leitura sobre modelos que vem sendo também exportados.

Essas são as linhas gerais das pesquisas futuras que dão continuidade a matriz já estabelecida nesse texto que resultou das primeiras análises sobre os encontros em Cartografia, Direito e Cadastro.

\section{Agradecimentos}

Este artigo faz parte de uma pesquisa desenvolvida com bolsa de produtividade em pesquisa PQ-2 do CNPq - Conselho Nacional de Desenvolvimento Científico de Tecnológico [Processo no. 307456/2018-8].

\section{Contribuição dos Autores}

Os autores contribuíram igualmente em todas as etapas de elaboração do artigo, da sua concepção e investigação à redação do texto final.

\section{Conflitos de Interesse}

Não há conflitos de interesse.

\section{Referências}

ÁlCAZAR MOLINA, M. G. Catastro, propiedad y prosperidad. Jaén, Espanha: Publicaciones de la Universidad de Jaén, 2007.

ARCÀ, A. Chapter 15 - The topographic engravings of Alpine rock-art: fields, settlements, and agricultural landscapes. In: CHIPPINDALE, C.; NASH G. The Figured Landscapes of Rock-Art: Pictures in Place. Cambridge, Grã-Bretanha: Cambridge University Press, 2004. p.318-349.

ARCHELA, R. S.; ARCHELA, E. Síntese cronológica da Cartografia no Brasil. Portal da Cartografia. 
Londrina: Brasil, v. 1, n. 1, 2008.

BERNARDINO, M. G. A. "O "Serviço da Carta": uma Análise Institucional da Comissão da Carta Geral do Brasil” (1903-1932). In: 13 SEMINÁRIO NACIONAL DE HISTÓRIA DA CIÊNCIA E DA TECNOLOGIA, 2012, São Paulo, Brasil. Anais do $\mathbf{1 3}^{\circ}$ Seminário Nacional de História da Ciência e da Tecnologia. São Paulo: EACH/USP. 2012. pp.1-8.

BRANDÃO, A. C. O princípio da vizinhança geodésica no levantamento cadastral de parcelas territoriais. 2003. 128p. Tese de Doutorado em Engenharia de Produção, UFSC, Florianópolis, Brasil, 2003.

BULLOCK, K. R. Design Principles for Land Information Systems (Unisurv Report), Kensigton, GrãBretanha: Scholl of Surveying, The University of New South Wales, 1983.

CLARKE, K. C. What is the World's Oldest Map? The Cartographic Journal, Londres, Grã-Bretanha, vol. 50, n. 2, p.136-143. 2013. doi.org/10.1179/0008704113Z.00000000079

COMPARATO, F. K. Revoluções no Campo Jurídico. Joinville, Brasil: Oficina Comunicações Editora, 1998.

COMISSÃO NACIONAL DE CARTOGRAFIA (CONCAR). Plano de Ação para a Implantação da INDE. Brasília, Brasil, 2010. Disponível em: < https://bibliotecadigital.seplan.planejamento.gov.br/bitstream/handle/iditem/309/PlanoDeAcaoINDE_Po rt.pdf?sequence=1\&isAllowed=y>. Acesso em: 23 dez. 2020.

DIRETORIA DE SERVIÇO GEOGRÁFICO (DSG). Diretoria do Serviço Geográfico do Exército Brasileiro. Disponível em: 〈http://www.dsg.eb.mil.br/index.php/histórico〉. Acesso em: 23 dez. 2020.

CUNHA, E; OLIVEIRA, F.; JULIÃO, R.; CARNEIRO, A. O cadastro urbano no Brasil: histórico e evolução. Revista de Geografia e Ordenamento do Território. Porto, Portugal, n.17, p.55-74, 2019. dx.doi.org/10.17127/got/2019.17.003.

DILKE, O. A. W. Chapter 5 - Cartography in the Ancient World: An Introduction. In: HARLEY, J. B.; WOODWARD, D. The History of Cartography, vol 1: Cartography in Prehistoric, Ancient, and Medieval Europe and the Mediterranean. Chicago, Estados Unidos da América: The University of Chicago Press, 1987. p.105-106.

FACHIN, L. E. Reflexões Sobre os Rumos da Reforma Agrária no Brasil. Separata da Revista de Informação Legislativa. Brasília: Brasil, v. 24, n. 96, p. 339-346, 1987.

FÉDÉRATION INTERNATIONALE DES GÉOMÈTRES (FIG). Statement on the Cadastre. FIG publications n.11. Copenhagen: International Federation of Surveyors (FIG), 1995. Disponível em: <https://www.fig.net/resources/publications/figpub/pub11/figpub11.asp>. Acesso em: 26 jul. 2020.

GESTEIRA, H. M. Observações astronômicas e físicas no Rio de Janeiro setecentista (1781-1787). Boletim Eletrônico da Sociedade Brasileira de História da Ciência. no. 5, 2015. Disponível em: < https://www.sbhc.org.br/conteudo/view?ID_CONTEUDO=838>. Acesso em 23 dez. 2020.

HARLEY, J. B.; WOODWARD, D. Chapter 8 - The Foundations of Theoretical Cartography in Archaic and Classical Greece. In: HARLEY, J. B.; WOODWARD, D. The History of Cartography, vol 1: Cartography in Prehistoric, Ancient, and Medieval Europe and the Mediterranean. Chicago, Estados Unidos da América: The University of Chicago Press, 1987. p.130-147.

IESCHECK, A. L.; ROCHA, R. S.; REISS, M. L. L. e FAGUNDES, M. A. R. A Cartografia e o Problema dos Referenciais Geodésicos: Comissão da Carta Geral do Brasil. In: V SIMPÓSIO BRASILEIRO DE CIÊNCIAS GEODÉSICAS E TECNOLOGIAS DA GEOINFORMAÇÃO, 2014, Recife, Brasil. Anais do V Simpósio Brasileiro de Ciências Geodésicas e Tecnologias da Geoinformação. Recife, Brasil: UFPE, 2012. p.200-205.

JEAN-COURRET, E. For a genetic and diplomatic approach to old cadastres: proposals and advice for editing cadastral sources. Imago Temporis: Medium Aevum, Espanha, no.14, p.25-60, 2020. doi.org/10.21001/itma.2020.14.01 
KONVITZ, J. W. The National Map Survey in Eighteenth-Century France. Government Publications Review, Amsterdã: Holanda, vol. 10, no. 4, p.395-403, 1983. https://doi.org/10.1016/02779390(83)90079-1

MAIA, J. M. E. A terra como invenção: o espaço no pensamento social brasileiro. Rio de Janeiro, Brasil: ZAHAR, 2008.

MAIA, P. C. Sesmarias. São Paulo, Brasil: Revista Editora dos Tribunais, 1955.

MENEZES, P. M. L. Cartografia do Império do Brasil e suas Triangulações. In: II SIMPÓSIO BRASILEIRO DE GEOMÁTICA e V COLÓQUIO BRASILEIRO DE CIÊNCIAS GEODÉSICAS, 2007, Presidente Prudente, Brasil. Anais do V Colóquio Brasileiro de Ciências Geodésicas. Curitiba, Brasil: CPGCG, 2007. p.1-6.

MILLARD, A. R. Chapter 6 - Cartography in the Ancient Near East. In: HARLEY, J. B.; WOODWARD, D. The History of Cartography, vol 1: Cartography in Prehistoric, Ancient, and Medieval Europe and the Mediterranean. Chicago, Estados Unidos da América: The University of Chicago Press, 1987. p.107116.

PHILIPS, J. O cadastro napoleônico. Boletim eletrônico do IRIB. BE829, 2003. Disponível em: < https://irib.org.br/boletins/detalhes/3008>. Acesso em: 27 jul. 2020.

PINTO, M. M. R. O profissional com procuração pública como responsável técnico pelo cadastro imobiliário para fins de registro público. 2001. 110p. Dissertação de Mestrado em Engenharia de Produção. UFSC. Florianópolis, Brasil, 2001.

PONTE RIBEIRO, D. Barão de. Carta do Império do Brasil. Rio de Janeiro, RJ: Archivo Militar, 1873. Mapa, $64 \mathrm{~cm}$ x $63 \mathrm{~cm}$, escala aproximada de 1:3.000.000

SHORE, A. F. Chapter 7 - Egyptian Cartography. In: HARLEY, J. B.; WOODWARD, D. The History of Cartography, vol 1: Cartography in Prehistoric, Ancient, and Medieval Europe and the Mediterranean. Chicago, Estados Unidos da América: The University of Chicago Press, 1987. p.117129.

SLOCUM, T.; MACMASTER, R. B.; KESSLER, F.; HOWARD, H. H. Thematic Cartography and Geovisualization. $3^{\mathrm{a}}$ edição. Estados Unidos da América: Prentice Hall, 2008.

SLUTER, C. R.; CAMBOIM, S. P.; IESCHECK, A.L.; PEREIRA, L. B.; CASTRO, M. C.; YAMADA, M. M. e ARAÚJO, V. S. A Proposal for Topographic Map Symbols for Large-Scale Maps of Urban Areas in Brazil. The Cartographic Journal, Londres: Grã-Bretanha, v. 55, n. 4, p. 362-377, 2018. 10.1080/00087041.2018.1549307.

TEPEDINO, G. Temas de Direito Civil. Rio de Janeiro: Renovar, 1999.

THE UNITED NATIONS ECONOMIC COMMISSION FOR EUROPE (UNECE). Land Administration in the UNECE Region: Development, Trends and Main Principles. New York and Geneva: United Nations $\quad 2005.2$ Dublications, em: < https://unece.org/DAM/hlm/documents/Publications/landadmin.devt.trends.e.pdf> Acesso em: 23 dez. 2020.

THROWER, N. J. W. Maps \& Civilization: Cartography in Culture and Society. $3^{\text {a }}$ ed. Londres, GrãBretanha: The University of Chicago Press, 2008.

WILLIAMSON, I.; ENEMARK, S. e RAJABIFARD, A. Land administration for sustainable development. In: XXIV FIG International Congress and Australian surveyors - FIG Congress 2010, Sidney, Australia. Proceedings: facing the challenges - building the capacity. Copenhagen, Dinamarca: International Federation of Surveyors, 2010. p.1-16.

WILLIAMSON, I. A modern cadastre for New South Wales (Unisurv Report). Kensigton, Grã-Bretanha: Scholl of Surveying, The University of New South Wales, 1983. 


\section{Biografias dos autores}
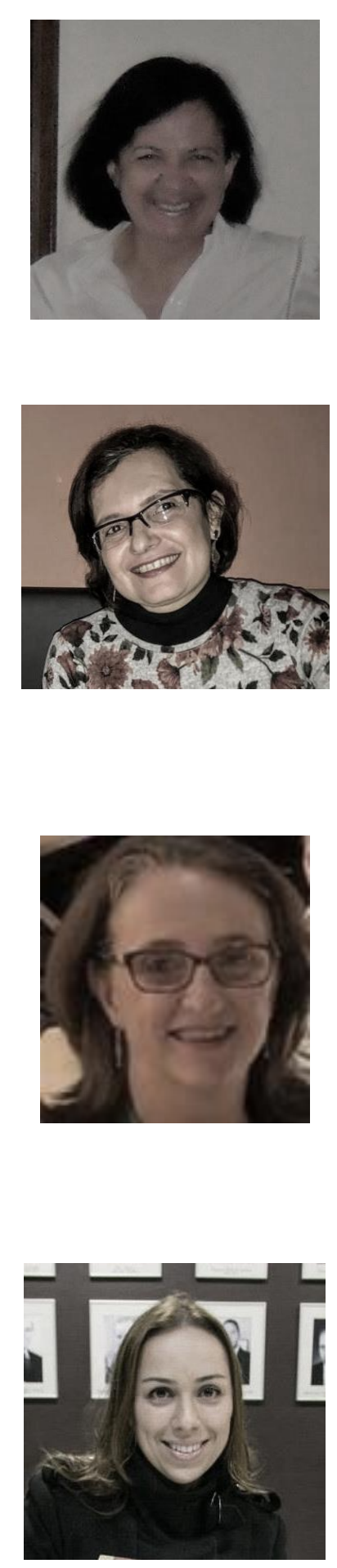

Claudia Robbi Sluter, Curitiba - PR - Brasil/1960. Possui graduação em Engenharia Cartográfica e mestrado em Ciências Geodésicas pela Universidade Federal do Paraná (UFPR), doutorado em Computação Aplicada pelo Instituto Nacional de Pesquisas Espaciais (INPE). É professora do Departamento de Geodésia da Universidade Federal do Rio Grande do Sul (UFRGS), em Porto Alegre - RS, Brasil. Atua no ensino de graduação e de pós-graduação na área de Geociências, com ênfase em Cartografia e Ciência da Geoinformação. No contexto atual da produção científica e acadêmica destacam-se os seguintes temas: geovisualização, projeto de soluções de geoinformação e mapeamento topográfico.

Andrea Flávia Tenório Carneiro, Arcoverde-PE-Brasil, 1966. Engenheira Cartógrafa pela Universidade Federal de Pernambuco - UFPE em 1989. Mestre em ciências geodésicas pela Universidade Federal do Paraná - UFPR em 1993 e doutora em engenharia de produção pela Universidade Federal de Santa Catarina UFSC em 2000. Realizou estágio pós-doutoral na Universidade Nova de Lisboa UNL em 2018. Docente do Departamento de Engenharia Cartográfica da UFPE desde 1994, em Recife-PE. Atua no ensino e pesquisa nas áreas de cadastro e gestão territorial nos cursos de engenharia cartográfica e de agrimensura e de pósgraduação em ciências geodésicas e tecnologias da geoinformação.

Andrea Lopes Iescheck, Curitiba - PR - Brasil/1965. Possui graduação em Engenharia Cartográfica, mestrado em Ciências Geodésicas e doutorado em Ciências Geodésicas pela Universidade Federal do Paraná (UFPR). É Professora do Departamento de Geodésia, Instituto de Geociências, da Universidade Federal do Rio Grande do Sul (UFRGS), em Porto Alegre - RS, Brasil. Atua no ensino de graduação e de pós-graduação na área de Geociências, com ênfase em Cartografia e Ciência da Geoinformação. No contexto atual da produção científica e acadêmica destacam-se os seguintes temas: visualização de volumes, modelagem tridimensional, qualidade de dados geoespaciais, infraestrutura de dados espaciais e mapeamento topográfico.

Daniele Regina Pontes, Porto Alegre/1976. Formada em Direito. Professora de Direito da Universidade Federal do Paraná (UFPR). Doutora em Direito pela UFPR (2012). Fui Coordenadora (2018-2020) e sou Professora do Programa de Pósgraduação em Planejamento Urbano da UFPR. Pesquisadora do Grupo de Pesquisa em Planejamento e Políticas Urbanas e Regionais - CEPPUR e coordenadora da linha de pesquisa em Direito, Terra e Cidade - DICIT da UFPR. Pesquisadora do Grupo de Pesquisa PRO POLIS/CCONS da UFPR. Pesquisadora do Grupo de Pesquisa em Direito Civil Constitucional da UFPR. Foi pesquisadora do Núcleo de Direito Cooperativo e Cidadania da UFPR. 


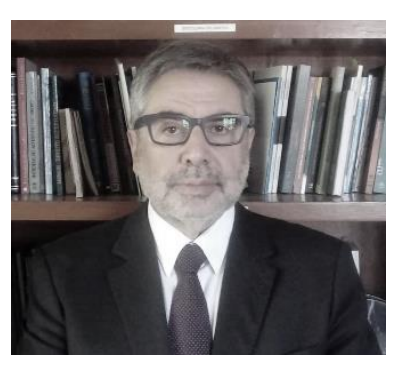

José Antônio Peres Gediel, natural de Quaraí, Rio Grande do Sul, nascido em 15 de setembro de 1953. Graduado pela Universidade Federal do Rio Grande do Sul, Mestre e Doutor pela Universidade Federal do Paraná. Realizou Estágio PósDoutoral junto à Universidade de Montréal, Canadá, foi Professor visitante na Universidade de Buenos Aires, Argentina, e na Universidade de Columbia, Nova Iorque, EUA (bolsista Capes). É Professor Titular de Direito da Universidade Federal do Paraná. Sua produção científica e atividades estão vinculadas às temáticas do Direito Civil, direitos da personalidade, autonomia corporal, biotecnologia, direito de propriedade, políticas públicas e Direitos Humanos. devido crédito pela criação original. 